\title{
Assessment of discharge and sediment transport from different forest cover types in lower Himalaya using Soil and Water Assessment Tool (SWAT)
}

\author{
J. V. Tyagi ${ }^{1 *}$, S. P. Rai ${ }^{1}$, Nuzhat Qazi $^{2}$ and M. P. Singh ${ }^{2}$ \\ ${ }^{1}$ National Institute of Hydrology, Jal Vigyan Bhawan, Roorkee - 247 667, Uttarakhand, India. \\ ${ }^{2}$ Forest Research Institute, Dehradun - 248006, Uttarakhand, India.
}

Accepted 22 November, 2013

\begin{abstract}
The present study was carried out to examine the applicability of Soil and Water Assessment Tool (SWAT) in estimating daily discharge and sediment delivery from mountainous forested watersheds and to assess the impact of forest cover types on stream discharge pattern and sediment load. The study watersheds namely Arnigad and Bansigad, comprising of dense Oak forest $(80 \%)$ and degraded Oak forest $(83 \%)$ respectively, are located in lower Himalaya (India). Apart from hill topography, deforestation in the watersheds results in huge loss of productive soil and water as runoff. Daily discharge, sediment concentration and other hydro-meteorological data were monitored at the outlet of each watershed. SWAT was calibrated and validated for daily discharge and sediment concentration using the observed data. The performance of the model was evaluated using the statistical measures of coefficient of determination $\left(R^{2}\right)$ and Nash-Sutcliffe efficiency $\left(E_{N S}\right)$. The statistical analysis of calibration results for Arnigad watershed showed very good agreement between observed and simulated daily values, with an $R^{2}$ value of 0.91 , and an $E_{N S}$ of $84.48 \%$ in discharge simulation; and an $R^{2}$ value of 0.89 , and an $E_{\mathrm{NS}}$ of $83.11 \%$ in sediment simulation. The model also exhibited high performance on Bansigad watershed with an $\mathrm{R}^{2}$ value of 0.91 , and an $\mathrm{E}_{\mathrm{NS}}$ of $89.74 \%$ in discharge simulation; and an $R^{2}$ value of 0.86 , and an $E_{N S}$ of $82.07 \%$ in sediment simulation. The model performed equally well on validation data and estimated the discharge and sediment yield very close to the observed data. The simulated mean annual water yield and sediment yield were also comparable to observed values in both the watersheds. The mean annual surface runoff and water yield over the entire study period were simulated as 6 and $59.4 \%$ respectively of the mean annual rainfall in Arnigad watershed; and 6.9 and $63.7 \%$ respectively in Bansigad watershed. The results of the study indicated that SWAT is capable of estimating the discharge and sediment yield from Himalayan forested watersheds and can be a useful tool for assessing hydrology and sediment yield response of the watersheds in the region.
\end{abstract}

Key words: Oak forest, soil and water assessment tool (SWAT), discharge, sediment concentration, calibration, water yield.

\section{INTRODUCTION}

In mountainous watersheds, especially in Himalayan region, the spatial and temporal variability in terms of soil, land use/land cover, topography, rainfall and biotic forest cover, as well as young geologic materials have interventions is large. The steep slopes along with depleted been major factors in soil erosion and sedimentation in river reaches (Jain et al., 2004). Runoff and sediment yield data is scarcely available for Himalayan watersheds 
which are often required for operation and management of irrigation and hydropower projects in the region. Reliable measurement of various hydrological parameters including runoff and sediment yield is also a difficult task in remote and inaccessible areas. The use of simulation models can partially solve the problem of hydrologic evaluation of watersheds in conditions with limited and unavailable data of discharge and sediment yield. A suite of physically based, spatially distributed hydrological models are now available. The USDAAgricultural Research Service (ARS) developed CREAMS model (Knisel, 1980) to simulate the long-term impact of land management on water leaving the edge of a field. Several other distributed models for hydrologic and pollutants transport modelling include ANSWERS (Beasley et al., 1980), GLEAMS (Leonard et al., 1987), EPIC (Williams et al., 1983), OPUS (Smith, 1992), AGNPS (Young et al., 1989) and SWRRB (Williams et al., 1985). These models were all developed for specific problems and have limitations for modelling watersheds with hundreds or thousands of sub-watersheds.

The soil and water assessment tool (SWAT) (Arnold et al., 1998), a physically based, spatially distributed model overcomes these limitations and is being increasingly used to assess the hydrological behaviour of large and complex watersheds. Rapid parameterization of hydrologic models can be derived using remote sensing (RS) and geographic information systems (GIS) as remotely sensed data provides valuable and up-to-date spatial information on natural resources and physical terrain parameters. Numerous studies have described the potential benefits and use of RS and GIS in hydrologic modelling (Hession and Shanholtz, 1988; Maidment, 1993; Srinivasan and Engel, 1991; Bhaskar et al., 1992; Pandey et al., 2005, 2009). Among others, the SWAT model has proven to be an effective tool for assessing water resource and nonpoint-source pollution problems for a wide range of environmental conditions. The model has been widely used in various regions and climatic conditions on daily, monthly and annual basis (Arnold et al., 1998; Mulungu and Munishi, 2007; Muttiah and Wurbs, 2002; Srinivasan et al., 2005; Tolson and Shoemaker, 2007) and for the watershed of various sizes and scales (Kannan et al., 2008, 2007). Rosenthal et al. (1995) tested SWAT predictions of stream flow volume for the Lower Colorado River basin $\left(8927 \mathrm{~km}^{2}\right)$ in Texas. A GIS-hydrologic model link was used to aid in forming input files. Stream flow was simulated for nine years for four stream gauge locations with 60 sub-watersheds. With no calibration, the model closely simulated monthly stream flow with a regression coefficient $\left(R^{2}\right)$ of 0.75 . Bingner (1996) evaluated the SWAT model in the Goodwin Creek Watershed $\left(21.31 \mathrm{~km}^{2}\right)$ located in northern Mississippi over a 10-year period. The land use of the watershed was primarily pasture and cultivated field. The Nash-Sutcliffe coefficients $\left(E_{N S}\right)$ and $R^{2}$ values computed with observed monthly flow were all around
0.80. Srinivasan et al. (1997) used the SWAT model to simulate hydrology from 1960 to 1989 in the Rio Grande/Rio Bravo river basin $\left(598,538 \mathrm{~km}^{2}\right)$ located in parts of the United States and Mexico. The simulated average annual flow rates were compared against USGS stream gauge records. Visual time-series plots and statistical techniques were used to evaluate the model performance.

In one of the few applications to study daily streamflow, Peterson and Hamlett (1998) used the SWAT model to simulate discharge in the Ariel Creek watershed (39.5 $\mathrm{km}^{2}$ ) of north eastern Pennsylvania. Model evaluation of daily flow prior to calibration revealed a deviation of runoff volume of $68.3 \%$ and a $R^{2}$ of -0.03 . Spruill et al. (2000) evaluated the SWAT model and parameter sensitivities were determined while modelling daily stream flow in a small central Kentucky watershed comprising an area of $5.5 \mathrm{~km}^{2}$ over a two year period. Stream flow data of 1996 were used for calibration and of 1995 were used for evaluation of the model. The $\mathrm{E}_{\mathrm{NS}}$ for monthly total flow was 0.58 for 1995 and 0.89 for 1996 , whereas for daily flows it was observed to be 0.04 and 0.19 . Oeurng et al. (2011) used SWAT to simulate discharge and sediment transport at daily time steps within the intensively farmed Save catchment in south-west France $\left(1,110 \mathrm{~km}^{2}\right)$ and concluded that simulated daily values matched the observed values satisfactorily. Ayana et al. (2012) applied SWAT model to Fincha watershed $\left(3,251 \mathrm{~km}^{2}\right)$, located in Western Oromiya Regional State, Ethiopia and estimated monthly sediment yield with $R^{2}$ of 0.82 and $E_{N S}$ of 0.80 during calibration and $R^{2}$ of 0.80 and ENS of 0.78 during the validation period. SWAT has also been successfully used for simulating runoff, sediment yield and water quality of small watersheds for Indian catchments (Pandey et al., 2009, 2005; Tripathi et al., 1999).

Tripathi et al. (2003) applied the SWAT model for Nagwan watershed $\left(92.46 \mathrm{~km}^{2}\right)$ with the objective of identifying and prioritizing of critical sub-watersheds to develop an effective management plan. The model was verified for monsoon season on daily basis for the year 1997 and on monthly basis for the years 1992 to 1998 for both surface runoff and sediment yield. Jain et al. (2010) calibrated and validated SWAT for estimating runoff and sediment yield from part of the Satluj river basin lying between Suni and Kasol in Western Himalaya. The $R^{2}$ values in estimating daily runoff and sediment yield were 0.33 and 0.26 respectively, while for monthly runoff and sediment yield these were computed as 0.62 and 0.47 respectively. They considered these values reasonably satisfactory for estimating runoff and sediment yield from remote watershed with limited data. The review of literature, in general, indicated that SWAT is capable of simulating hydrological processes with reasonable accuracy. However, studies related to applicability of SWAT to the watersheds located in Himalayan region of India are rarely available in literature. The present study 


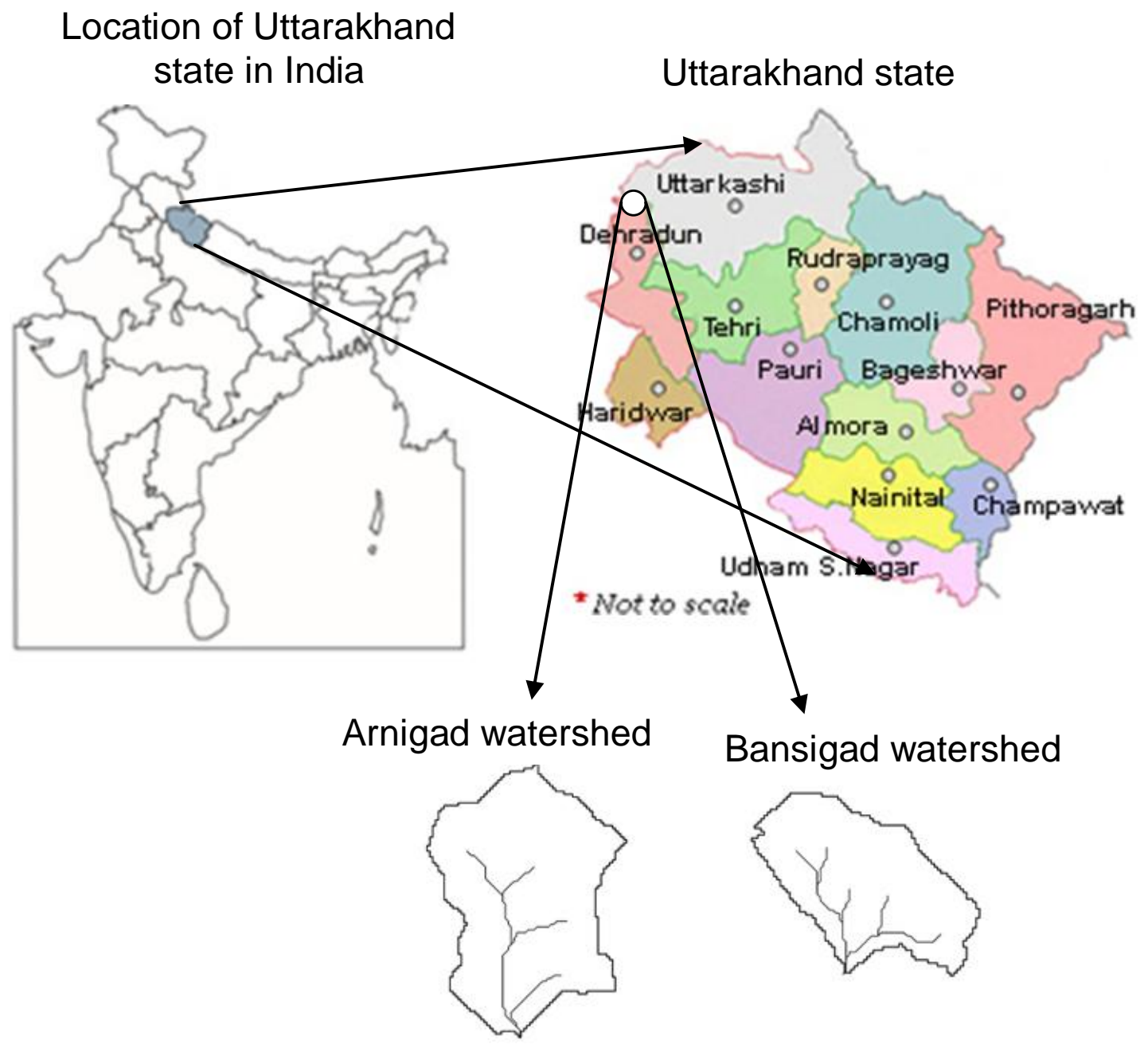

Figure 1. Location of study watersheds.

aims at examining the applicability of SWAT in simulating the hydrological and sediment response of dense and degraded Oak forest covers that predominantly occupy Arnigad and Bansigad watersheds respectively in lower Himalaya (India).

The Specific objectives of the study were to: i) measure rainfall, runoff and sediment concentration and other hydro-meteorological parameters in the watersheds, ii) calibrate and validate SWAT for the study watersheds using the measured data and assess its applicability in simulating daily discharge and sediment transport from forested mountainous watersheds, and iii) assess the impact of different forest cover types on stream discharge pattern and sediment yield.

\section{STUDIED WATERSHEDS}

Two small watersheds namely, Arnigad $\left(30^{\circ} 26^{\prime} 13.9^{\prime \prime} \mathrm{N}\right.$, $\left.78^{\circ} 05^{\prime} 37.4^{\prime \prime} \mathrm{E}\right)$ and Bansigad ( $30^{\circ} 27^{\prime} 9.1^{\prime \prime} \mathrm{N}, 78^{\circ} 02^{\prime}$
45.9" E), located $36 \mathrm{~km}$ North of Dehradun near Mussoorie (situated on the first mountain ridge beyond Dehradun) in Uttarakhand state of India were selected for the present study (Figure 1). The Arnigad (304.4 ha) and Bansigad (209.8 ha) watersheds are predominantly covered with moderately dense Oak forest and moderately degraded mixed Oak forest, respectively. The landform of both the watersheds consists of rugged, mountainous terrain with steep slopes. The elevation in Arnigad and Bansigad ranges between 2,220 to $1,640 \mathrm{~m}$ above $\mathrm{msl}$ and 2,160 to $1,620 \mathrm{~m}$ above msl, respectively. The mean orientation of both the watersheds is south. The drainage pattern of both the micro-watersheds is of dendritic type. The annual rainfall in Mussoorie is about $2005 \mathrm{~mm}$ of which 60 to $85 \%$ is received during monsoon season (June to September). In Mussoorie, the mean annual air temperature is $13.7^{\circ} \mathrm{C}$. The hottest month is June with an average (1961 to 1995) air temperature of $19.8^{\circ} \mathrm{C}$, and the coldest month is January with an average air temperature of $6^{\circ} \mathrm{C}$. 
The Mussoorie range, constituting the Proterozoic to lower Cambrian rocks of the lesser Himalaya is separated from the Cainozoic Siwalik Group and the Dun gravels by the MBT (Thakur and Pandey, 2004), that is a north-northeast dipping thrust along which the lesser Himalayan rocks are thrust over the Siwaliks (Rautela et al., 2010). The main parent material in this area consists of quartzite, schist, slates, phyllite, hard sandstones, limestone and dolomite (Bartarya, 1995).

\section{BRIEF DESCRIPTION OF SWAT MODEL}

SWAT 2005 with ArcSWAT interface was used in the present study. SWAT is a continuous, physically based distributed model that operates on a daily time step at watershed scale for long-term simulation of hydrology, sediment and agricultural chemical movement (Arnold et al., 1998). SWAT can analyse small or large catchments by discretising into sub-basins, which are then further subdivided into hydrological response units (HRUs) with homogeneous land use, soil type and slope. The SWAT system embedded within ARCGIS can integrate various spatial environmental data including soil, land cover, climate and topographical features. SWAT estimates daily volume of overland rainfall excess over each HRU by solving the water budget components of precipitation, runoff, evapotranspiration, percolation and return flow from subsurface and groundwater flow (Arnold et al., 1998). The model uses the Green-Ampt method or the modification of the SCS curve number method (USDA Soil Conservation Service, 1972) to compute surface runoff volume. Peak runoff rate is estimated using a modification of the 'rational method' (Chow et al., 1998). The measured daily potential evapotranspiration can be loaded directly for the watershed or determined using the Penman-Monteith method, the PriestleyTaylor method or the Hargreaves method (Arnold et al., 1998). Lateral subsurface flow is simulated using kinematic storage model, whereas empirical approaches are adopted for groundwater (Arnold et al., 1998; Borah and Bera, 2003; Neitsch et al., 2005).

In SWAT, Manning's equation is used to estimate flow rate and velocity through channels. Flow routing is based on either the variable storage or the Muskingum routing method (Neitsch et al., 2005). In the present study, SCS curve number and Muskingum routing methods, along with daily climate data, were used for surface runoff and streamflow computations. The Penman method was used to estimate potential evapotranspiration. SWAT uses the modified universal soil loss equation (MUSLE) (Williams, 1975) for computing the soil loss for each HRU. The sediment concentration is obtained from the sediment yield, which corresponds to flow volume within the channel on a given day. The transport of sediment in the channel is controlled by simultaneous operation of two processes: deposition and degradation. Whether channel deposition or channel degradation occurs depends on the sediment loads from the upland areas and the transport capacity of the channel network.

\section{MODEL INPUT DATA}

The basic spatial input datasets used by the model include the digital elevation model (DEM), land use/cover data, soil data and climatic data. The brief methodology for preparation of the data is described as follows:

\section{Digital elevation model}

DEM is one of the main inputs of the SWAT model to define topography of the study area. Elevation contours at $20 \mathrm{~m}$ interval were digitized from Survey of India toposheet (no. $53 \mathrm{~J} / 3$ ) at 1:50,000 scale using ARCGIS software. The digitized contours were used to generate DEM (Figure $2 a$ and $2 b$ ) with a grid cell resolution of $30 \mathrm{~m}$. The DEM was used to delineate the boundary of the watershed and analyze the drainage patterns of the land surface terrain. Terrain parameters such as slope gradient and slope length, and stream network characteristics such as channel slope, length and width were derived from the DEM.

\section{Land use/cover data}

Land use is one of the most important factors that affect runoff, soil erosion and evapotranspiration in a watershed during simulation (Neitsch et al., 2005). As per the Survey of India toposheet, major land use in Arnigad and Bansigad watersheds consists of oak forest with small areas under habitation and barren lands. The extent of various land use classes shown in the Survey of India toposheet $(1: 50,000$ scale) was verified in the field and minor modifications were made in the boundaries of land use classes as per actual extent. For preparation of land use map, the field surveyed land use classes were digitized and converted to raster format with grid cell size of $30 \mathrm{~m}$. The generated land use maps of Arnigad and Bansigad watersheds are shown in Figure 3(a and $b)$. The various land use categories and their coverage in both the study watersheds are presented in Table 1.

\section{Soil data}

The soil textural and physicochemical properties required by SWAT model include soil texture, available water content, hydraulic conductivity, bulk density and organic carbon content for each soil type. Undisturbed soil samples were collected from the depths of 0 to 15 and 15 to $30 \mathrm{~cm}$ using core samplers from five locations in each watershed. The collected soil samples were analysed in a standard soil laboratory for particle size distribution, bulk density, soil organic carbon and hydraulic conductivity. The available water content was calculated by subtracting the moisture content at wilting point from that at field capacity. Texturally, the soils in both the study watersheds were sandy loam soils. The average values of soil properties for Arnigad and Bansigad watersheds are presented in Table 2.

\section{Weather data}

Meteorological observatories were established within each watershed to monitor daily rainfall, temperature, humidity and wind velocity. Rainfall was measured using tipping bucket rain gauge linked with a data-logger system, and also with ordinary rain gauge for cross check. Maximum and minimum temperature, relative humidity and wind velocity were measured with the help of maximum to minimum thermometers, dry-wet bulb thermometers and anemometer respectively. The meteorological data was collected from March 2008 to February 2011.

\section{Hydrological and sediment yield data}

The daily discharge and suspended sediment concentration for the period of March 2008 to February 2011 were measured at the outlets of each study watershed. A sharp-crested weir with apex angle of $120^{\circ}$ was constructed at the medial line of flow and a digital stage level recorder was used to measure stream stage. Daily discharge was calculated using appropriate weir formula. The water samples were collected using Punjab bottle samplers and analysed in the laboratory for sediment concentration. Sediment 


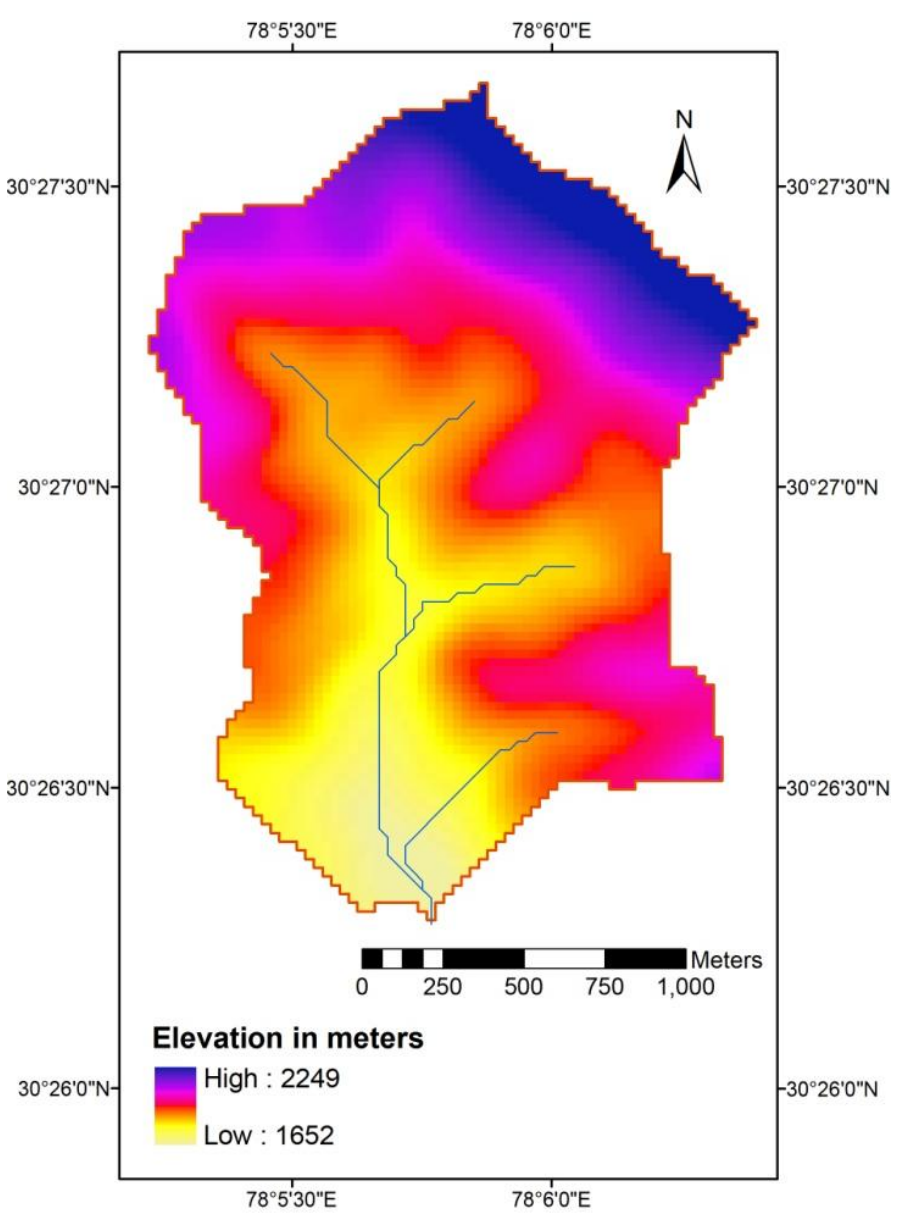

Figure 2a. DEM of Arnigad watershed.

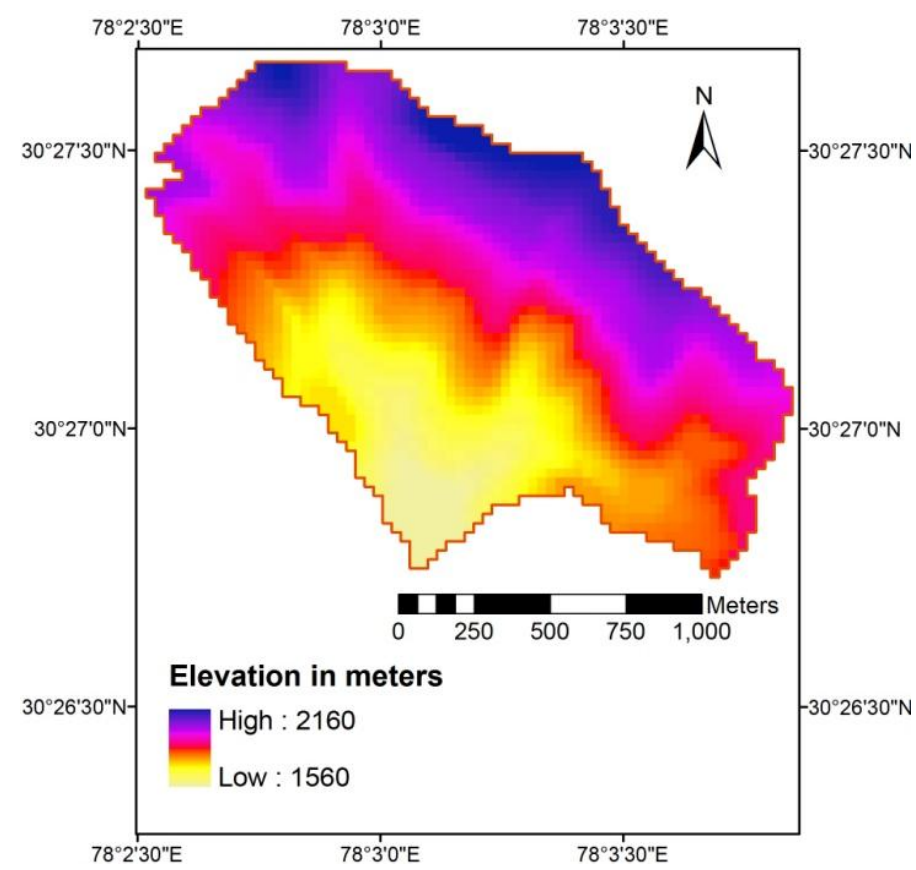

Figure $\mathbf{2 b}$. DEM of Bansigad watershed.

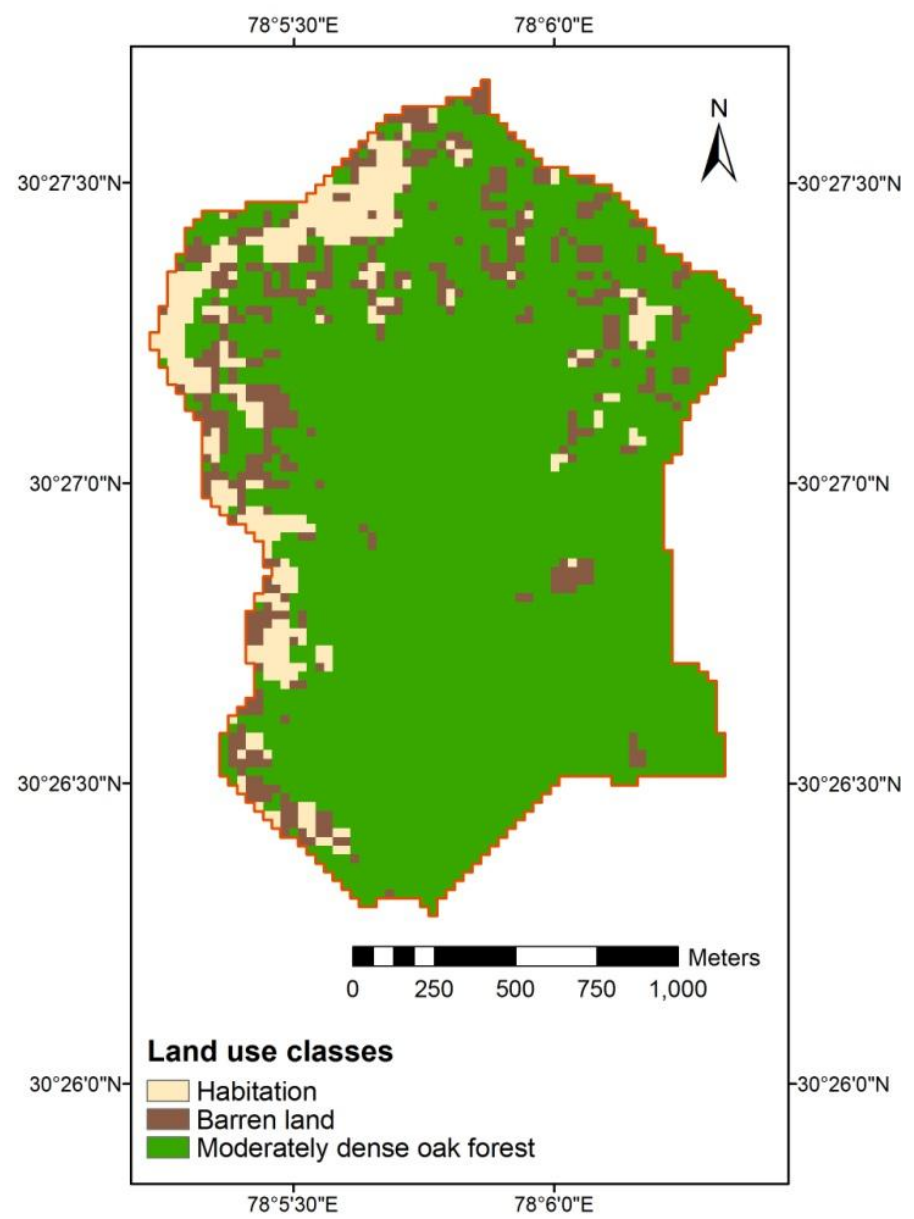

Figure 3a. Land use map of Arnigad watershed.

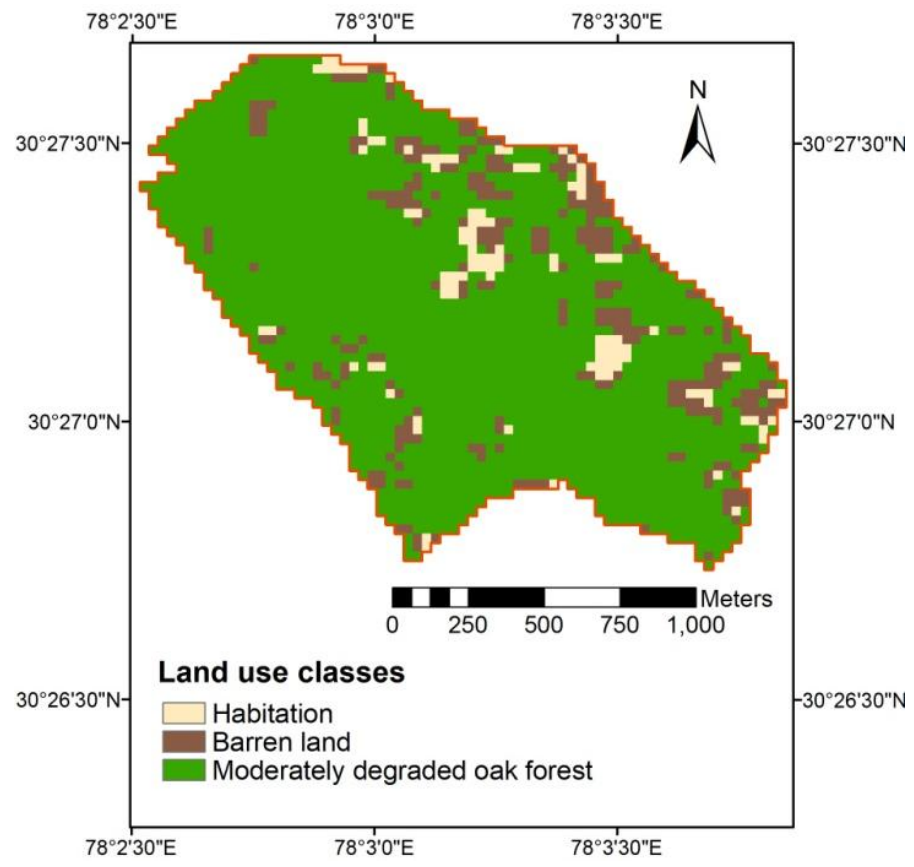

Figure $\mathbf{3 b}$. Land use map of Bansigad watershed. 
Table 1. Major land use classes in Arnigad and Bansigad watersheds

\begin{tabular}{lcccc}
\hline \multirow{2}{*}{ Land use } & \multicolumn{2}{c}{ Arnigad watershed } & \multicolumn{2}{c}{ Bansigad watershed } \\
\cline { 2 - 5 } & Area (ha) & \% total & Area (ha) & $\%$ total \\
\hline Dense Oak forest & 244.2 & 80.22 & 0 & 0 \\
Degraded Oak forest & 0 & 0 & 174.2 & 83.03 \\
Barren & 33.8 & 11.10 & 25.7 & 12.25 \\
Habitation & 26.4 & 8.68 & 9.9 & 4.72 \\
Total & 304.4 & 100 & 209.8 & 100 \\
\hline
\end{tabular}

concentration was measured by filtering samples through Whatman filter paper no. 42. The flow and suspended sediment concentration were measured over a range of hydrological conditions and daily values were calculated from the mean of instantaneous values for a given day.

\section{APPLICATION OF SWAT}

\section{Model set-up}

The ArcSWAT interface was used for the setup and parameterization of the model. A digital elevation model (DEM) was imported into the SWAT model. A masking polygon (in grid format) was loaded into the model in order to extract the area of interest, delineate the boundary of the watershed and digitize the stream network in the study area. The minimum threshold area for generation of streams was taken as 20 ha that divided Arnigad and Bansigad watersheds into seven and nine sub-watersheds (Figure $4 \mathrm{a}$ and $4 \mathrm{~b}$ ) respectively. The land use/cover and soil maps of the study watersheds (in grid format) were also imported into the model and overlaid to obtain a unique combination of land use, soil and slope. Multiple HRUs with 10\% land use and 10\% slope thresholds were set to eliminate minor land uses and slope classes in each sub-watershed as recommended in the SWAT user manual (Neitsch et al., 2002). A total of 15 and $21 \mathrm{HRUs}$ were delineated in Arnigad and Bansigad watersheds respectively. The daily data of rainfall, minimum and maximum temperature, relative humidity, wind speed and solar radiation were prepared in the appropriate file format and imported into the model.

\section{Model calibration and validation}

The calibration and validation were carried out at daily time steps using flow and suspended sediment concentration data. The calibration was performed using the data from June 2008 to May 2010. The data for the period of March 2008 to May 2008 were utilized for warming up and initialization of the model variables. The warm up period was not used for evaluation of the model predictions. The SWAT model includes a large number of parameters that describe different hydrological conditions and characteristics across the watershed. These

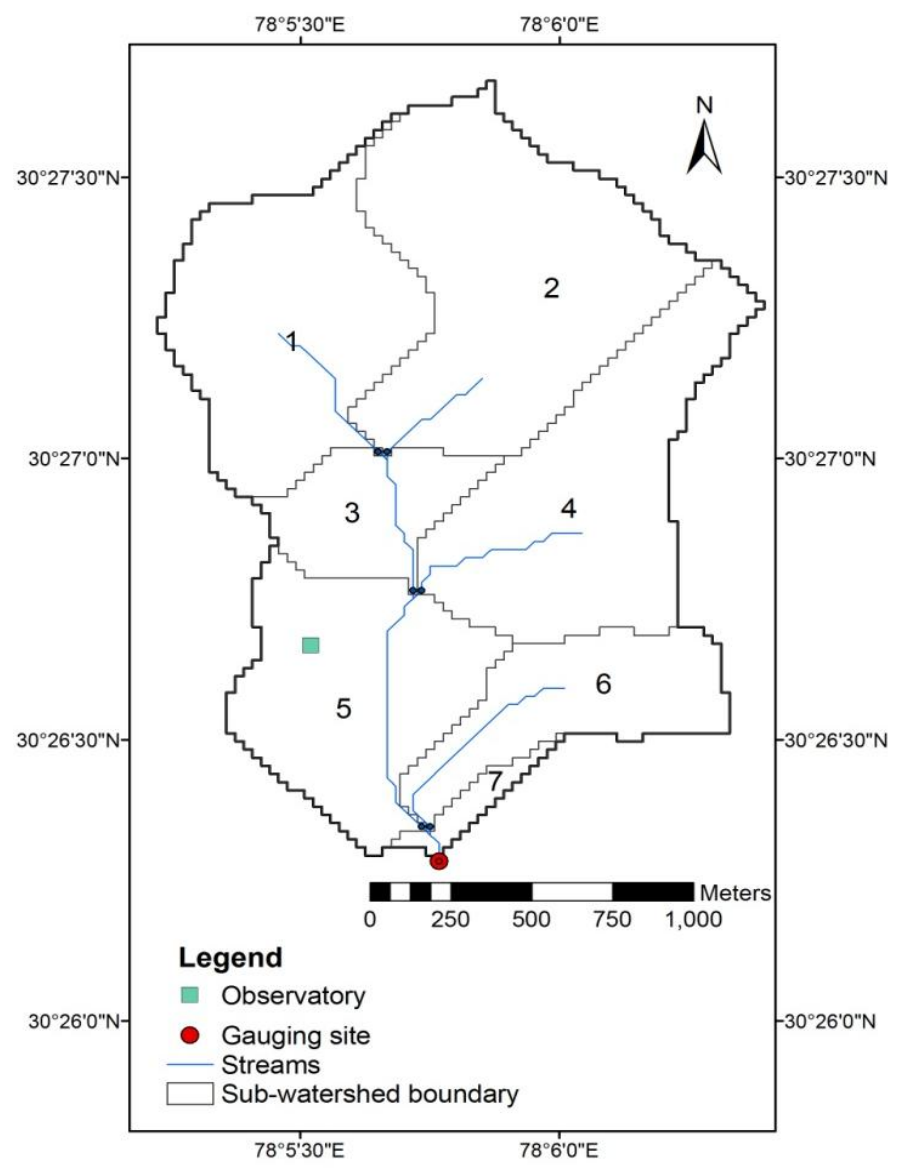

Figure 4a. Sub-watershed delineation in Arnigad watershed.

parameters need to be calibrated to adequately simulate streamflow and sedimentation processes in the study watersheds. Parameters can either be calibrated manually or automatically. In this study, the calibration was done manually based on physical catchment understanding and sensitive parameters from published literature (Bärlund et al., 2007; Xu et al., 2009) and calibration techniques from the SWAT user manual. The hydrological component and the erosion component of the model were calibrated sequentially until the average simulated and measured values were in close agreement. Results of many studies have indicated that SCS curve number $\left(\mathrm{CN}_{2}\right)$, a function of soil permeability, 


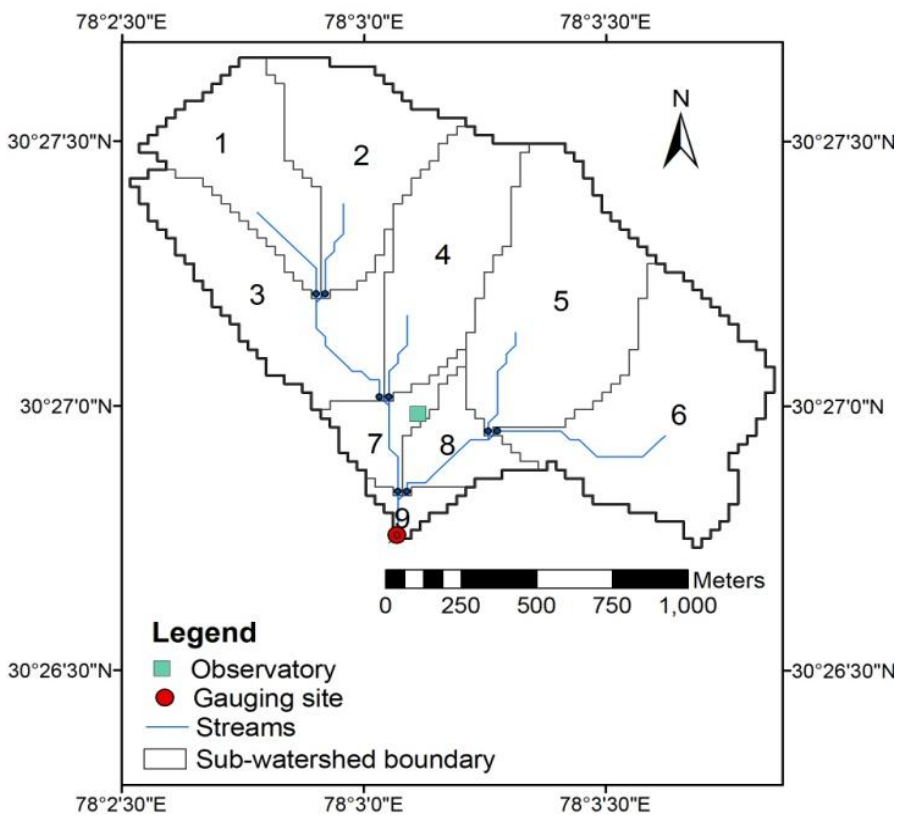

Figure 4b. Sub-watershed delineation in Bansigad watershed.

landuse and antecedent soil water conditions, is an important parameter for surface runoff (Oeurng et al., 2011; Das et al., 2007; Parajuli et al., 2007; Arabi et al., 2008; Wang et al., 2008). Since the base flow forms a significant part of the total flow in the study watersheds, the baseflow recession coefficient (ALPHA_BF) was calibrated for simulation of base flow.

The other important parameters that were calibrated for prediction of flow included 'soil evaporation compensation factor' (ESCO), 'plant water uptake compensation factor' (EPCO), 'surface runoff lag time' (SURLAG), 'groundwater delay' (GW_DELAY), 'deep aquifer percolation factor' (RCHRG_DP), 'Manning's " $n$ " value for tributary channels' (CH_N1), 'Manning's " $n$ " value for main channel' ( $\left.\mathrm{CH} \_\mathrm{N} 2\right)$ and 'Maining's "N" for overland flow' (OV_N). SWATT uses MUSLE (Williams, 1975) for prediction of sediment concentration. Therefore, the MUSLE "crop cover and management factor' (C) and the channel sediment routing variables, namely, a linear parameter for calculating the maximum amount of sediment that can be entrained during channel sediment routing (SPCON), an exponential parameter for calculating the channel sediment routing (SPEXP) were adjusted during the calibration. In the validation process, the model was run with calibrated input parameters and the model predictions were compared with an independent set of observed data of the period of June 2010 to February 2011.

\section{Criteria for model evaluation}

Several statistical measures are available for evaluating the performance of a model. In the present study, the performance of the model in simulating discharge and sediment was evaluated graphically and by NashSutcliffe efficiency $\left(E_{N S}\right)$ and coefficient of determination $\left(R^{2}\right)$. The Nash and Sutcliffe (1970) efficiency is one of the most frequently used criteria and is expressed in percentage form as:

$E_{N S}=\left\{1-\frac{\sum_{i=1}^{n}\left(O_{i}-S_{i}\right)^{2}}{\sum_{i=1}^{n}\left(O_{i}-\bar{O}\right)^{2}}\right\} \times 100$

Where $\mathrm{O}_{i}$ and $\mathrm{S}_{i}$ are the observed and simulated values, $\mathrm{n}$ is the total number of paired values and $\overline{\mathrm{O}}$ is the mean observed value.

The efficiency varies from 0 to 100 with 100 denoting perfect fit. Generally, $E_{N S}$ is very good when $E_{N S}$ is greater than $75 \%$, satisfactory when $E_{N S}$ is between 36 and $75 \%$, and unsatisfactory when $\mathrm{E}_{\mathrm{NS}}$ is lower than $36 \%$ (Nash and Sutcliffe, 1970; Krause et al., 2005). However, a shortcoming of the Nash-Sutcliffe statistic is that it does not perform well in periods of low flow, as the denominator of the equation tends to zero and $E_{N S}$ approaches negative infinity with only minor simulation errors in the model (Oeurng et al., 2011). This statistic works well when the coefficient of variation for the data set is large.

The coefficient of determination $\left(R^{2}\right)$ is the proportion of variation explained by fitting a regression line and is viewed as a measure of the strength of a linear relationship between observed and simulated data. It is computed as:

$R^{2}=\left\{\frac{\sum_{i=1}^{n}\left(O_{i}-\bar{O}\right)\left(S_{i}-\bar{S}\right)}{\left[\sum_{i=1}^{n}\left(O_{i}-\bar{O}\right)^{2}\right]^{0.5}\left[\sum_{i=1}^{n}\left(S_{i}-\bar{S}\right)^{2}\right]^{0.2}}\right\}$

Where $\overline{\mathrm{S}}$ is the mean of simulated values, $\mathrm{R}^{2}$ ranges between 0 and 1 . The value of 1 implies that the computed values are in perfect agreement with the observed data.

\section{RESULTS AND DISCUSSION}

\section{Assessment of calibration results}

The observed and simulated daily runoff and sediment concentration during calibration period of June 2008 to May 2010 are graphically presented in Figure $5(a, b)$ for Arnigad and Figure 6(a and b) for Bansigad watershed. It can be observed that the simulated discharge generally followed the trend to observed discharge in both the watersheds. A critical comparison of the runoff hydrographs of Arnigad watershed (Figure 5a) shows that the flow peaks are simulated slightly higher than the observed peaks during monsoon seasons both in 2008 and 2009. However, the low flows simulated by the model 


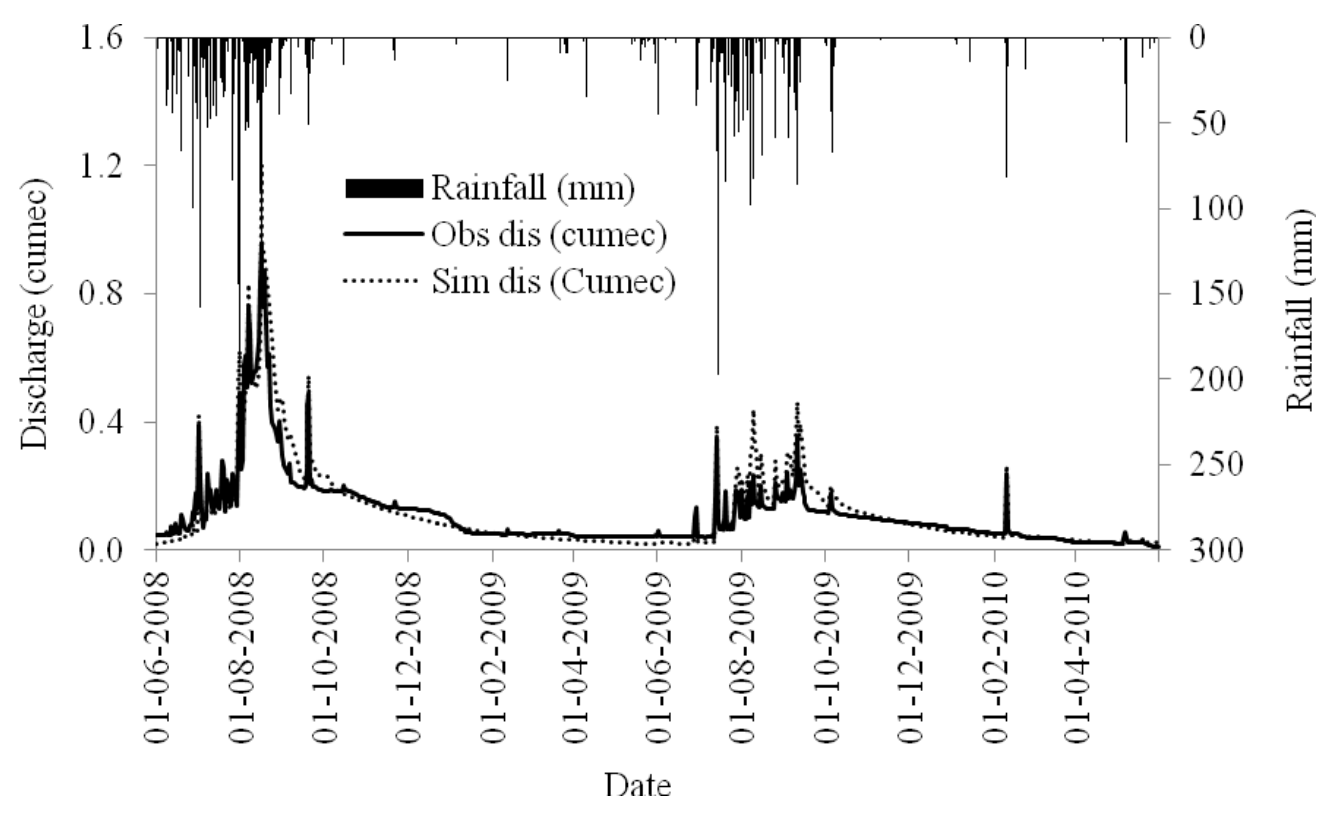

Figure 5a. Observed and simulated daily discharge during calibration in Arnigad watershed.

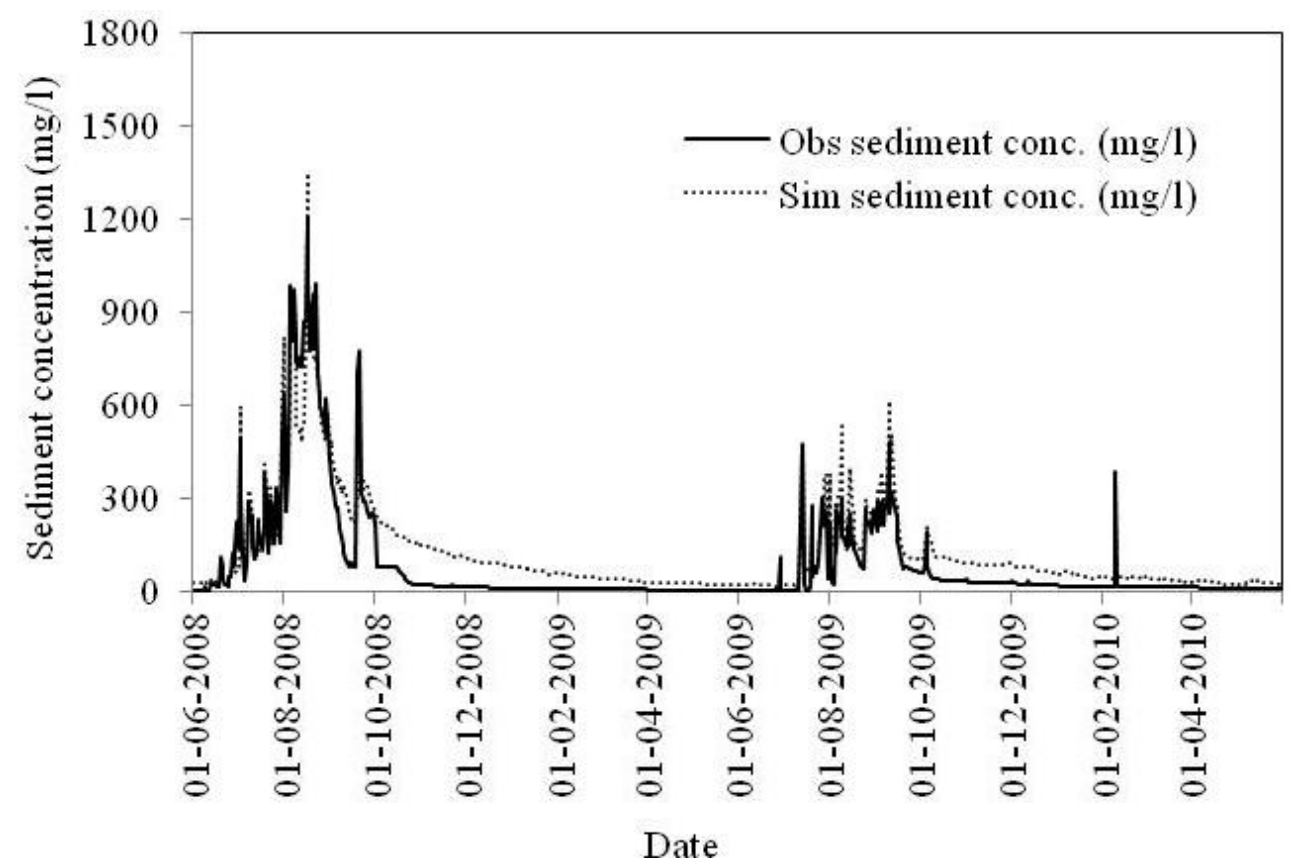

Figure 5b. Observed and simulated daily sediment concentration during calibration in Arnigad watershed.

generally match well with the observed values. In Bansigad watershed, a mixed trend is observed in simulating flows during 2008 and 2009; while, high and low flows are simulated reasonably well during 2008; the high flows appear to be underestimated and low flows overestimated during 2009. A comparison of observed and simulated suspended sediment concentration (Figures
$5 \mathrm{~b}$ and $6 \mathrm{~b}$ ) shows that simulated sediment concentration also generally followed the observed trend in both the watersheds. Although, model predicted peak values were found both higher and lower than the observed values at different times in both watersheds, the difference was within reasonable limits. The difference in simulated and observed values could occur due to the fact that in 


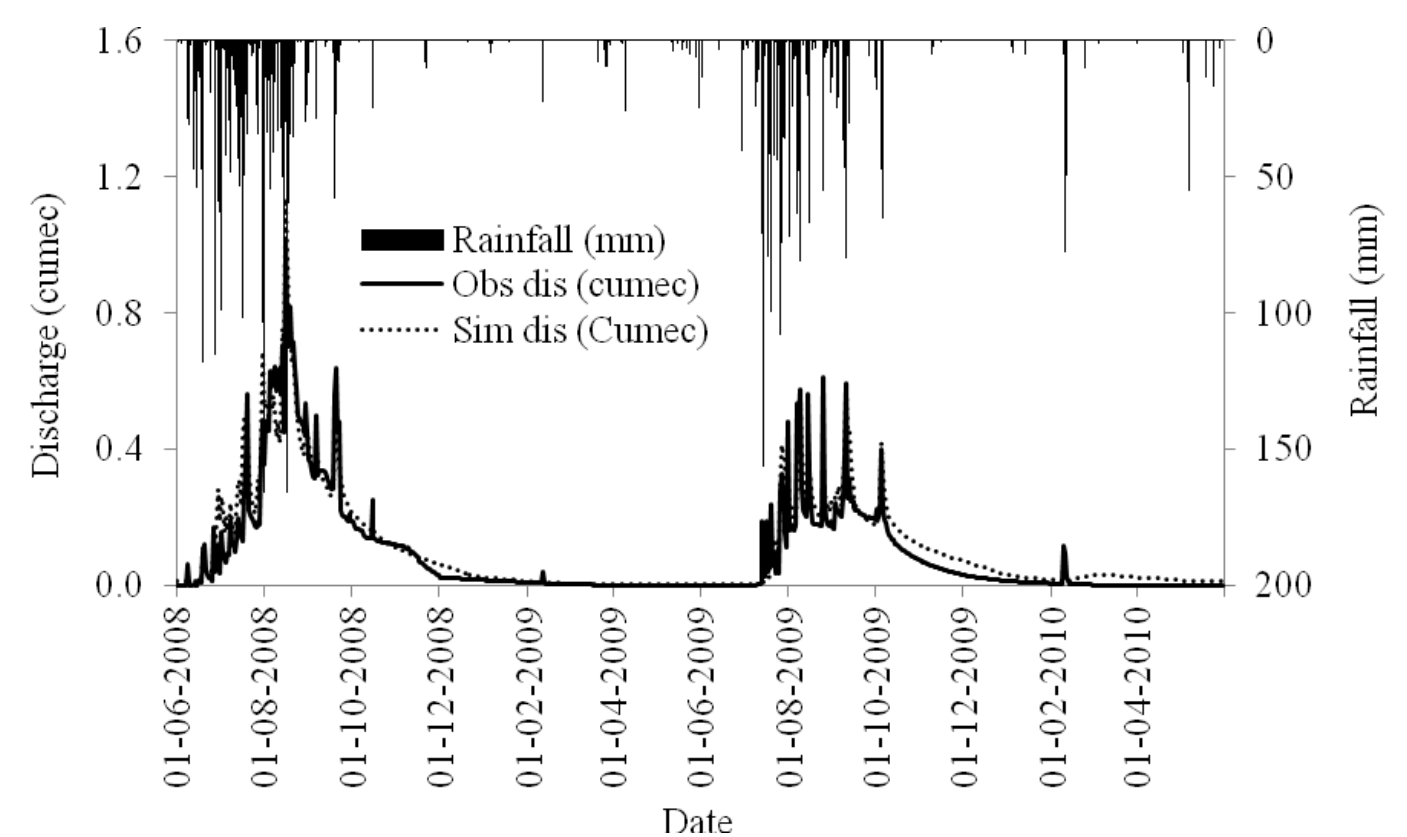

Figure 6a. Observed and simulated daily discharge during calibration in Bansigad watershed.

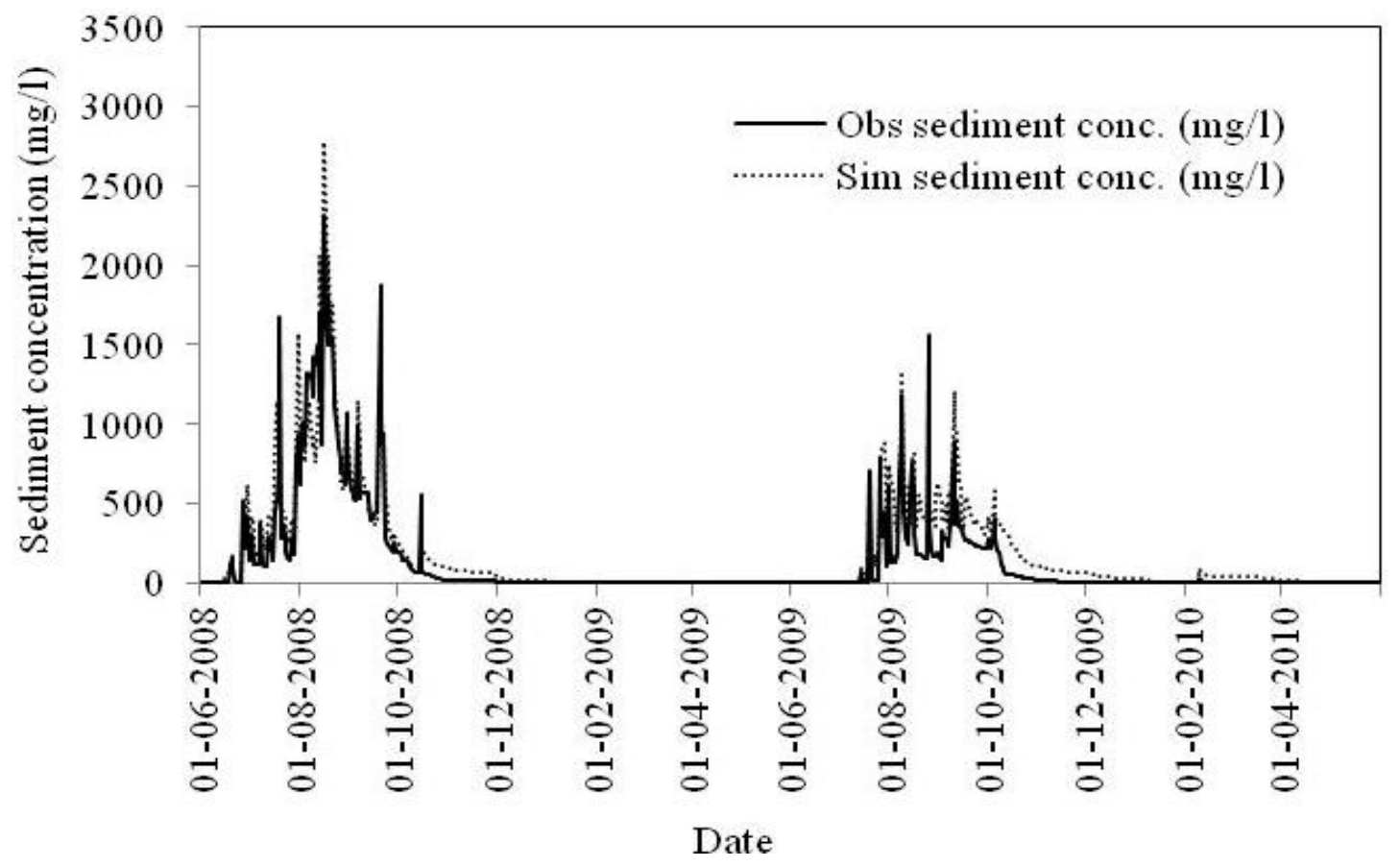

Figure 6b. Observed and simulated daily sediment concentration during calibration in Bansigad watershed.

practice, high-intensity and even short duration rainfall can generate more sediment than simulated by the model on the basis of daily rainfall (Xu et al., 2009). The simulated sediment concentration during non monsoon seasons was higher than the observed values in Arnigad watershed.

The obvious reason for higher sediment simulation is that the sediment response follows the simulated runoff rate as the sediment generation is largely determined by the runoff quantity. In Bansigad watershed, the simulation of sediment concentration during non monsoon seasons was reasonably good. The observed daily flows and sediment concentration were plotted against simulated daily flows and sediment concentration along with 1:1 line 


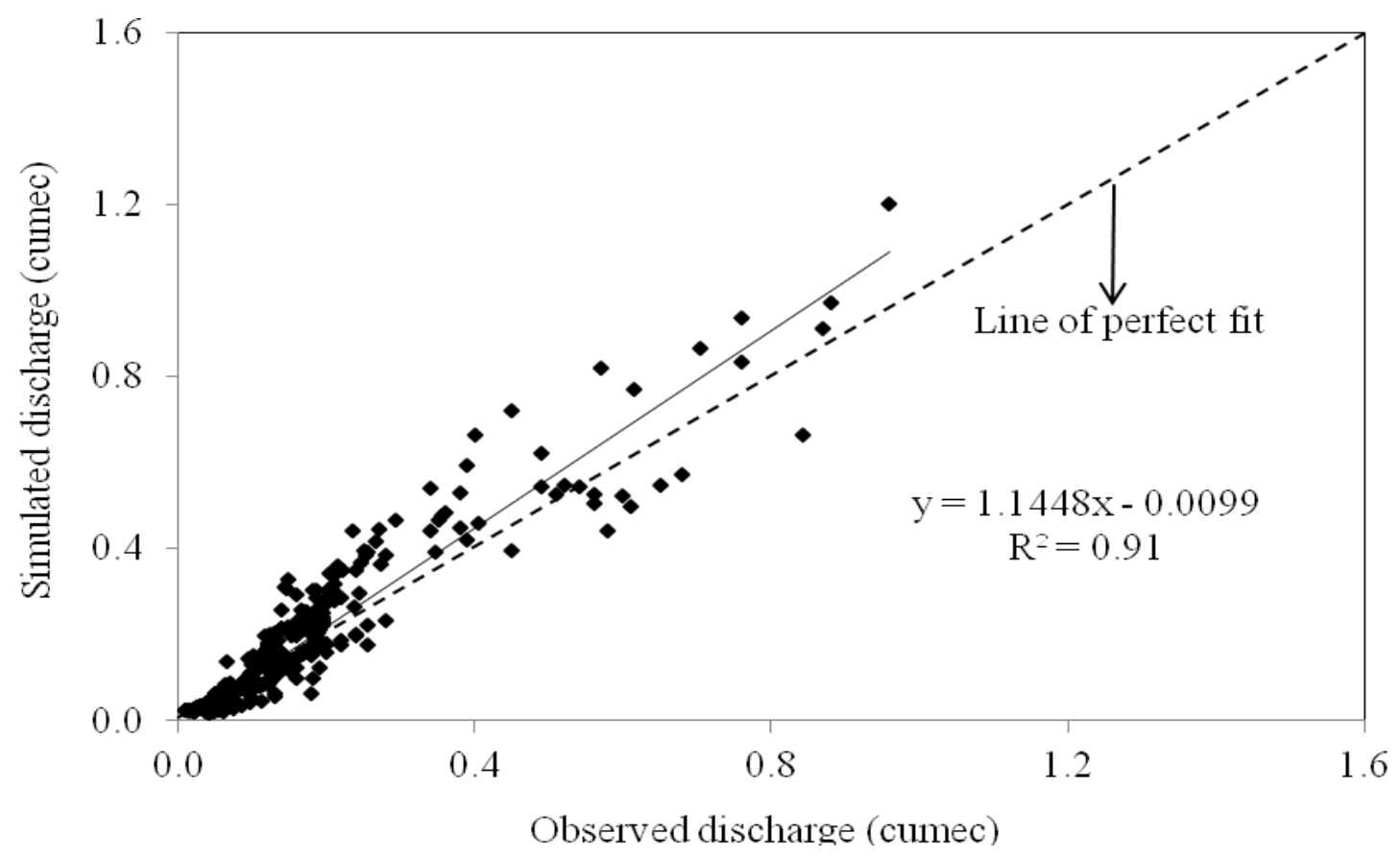

Figure 7a. Scatter plot of observed and simulated daily discharge during calibration in Arnigad watershed.

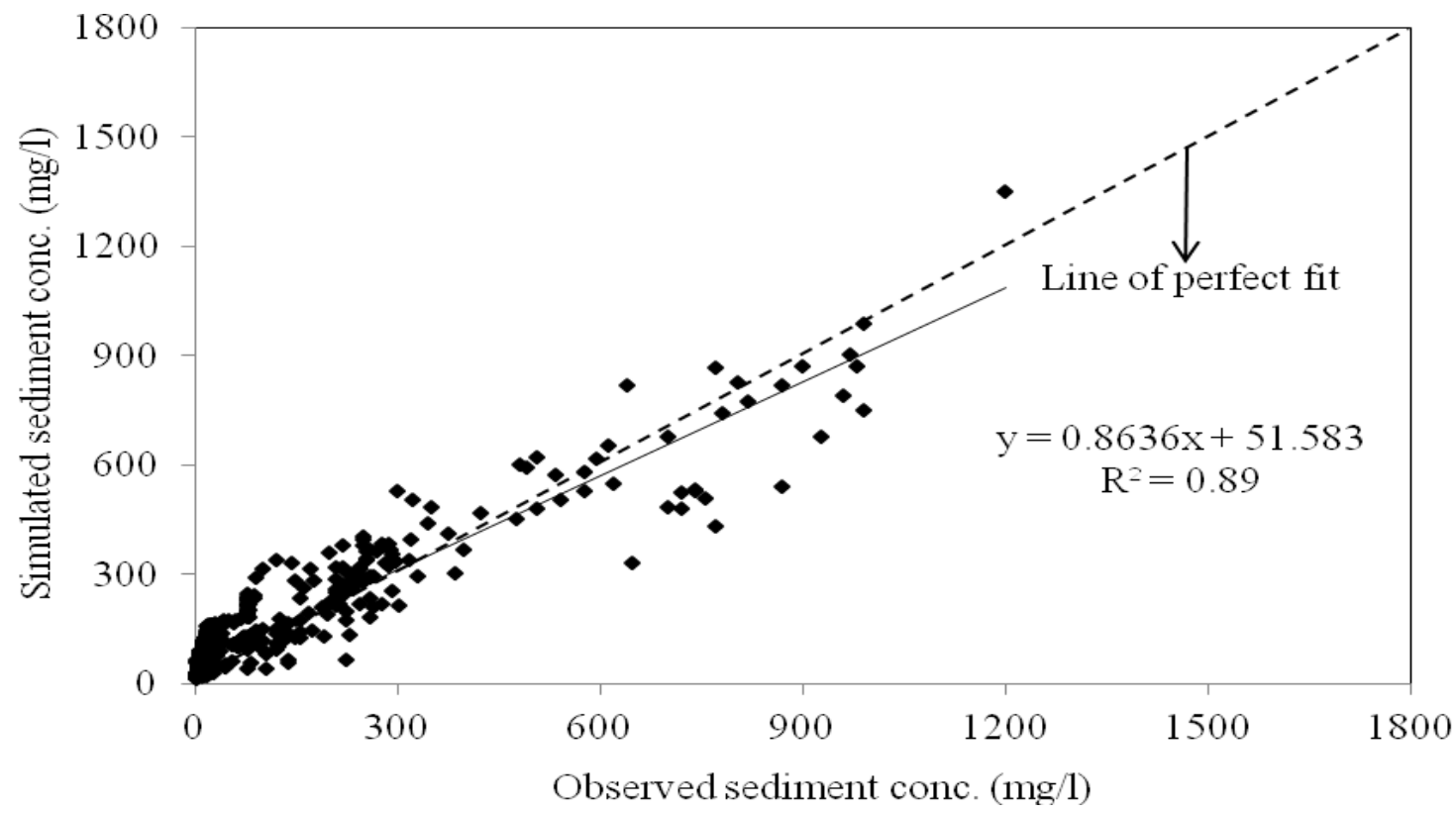

Figure $7 \mathrm{~b}$. Scatter plot of observed and simulated daily sediment concentration during calibration in Arnigad watershed.

(line of perfect fit) as shown in Figure $7(a, b)$ for Arnigad and Figure $8(\mathrm{a}$ and $\mathrm{b})$ for Bansigad watershed. It is observed from Figure $7 \mathrm{a}$ that the simulated runoff values are distributed uniformly about the 1:1 line for low values of observed runoff. For high values of observed runoff, majority of the simulated values are slightly above the line of perfect fit, indicating that the model over-predicts the high values of runoff. A close observation of Figure 8 a shows two clusters of data scatter, one cluster for low flows where most data lie above line of perfect fit indicating overestimation, and another cluster for high flows where most data lie below line of perfect fit that 


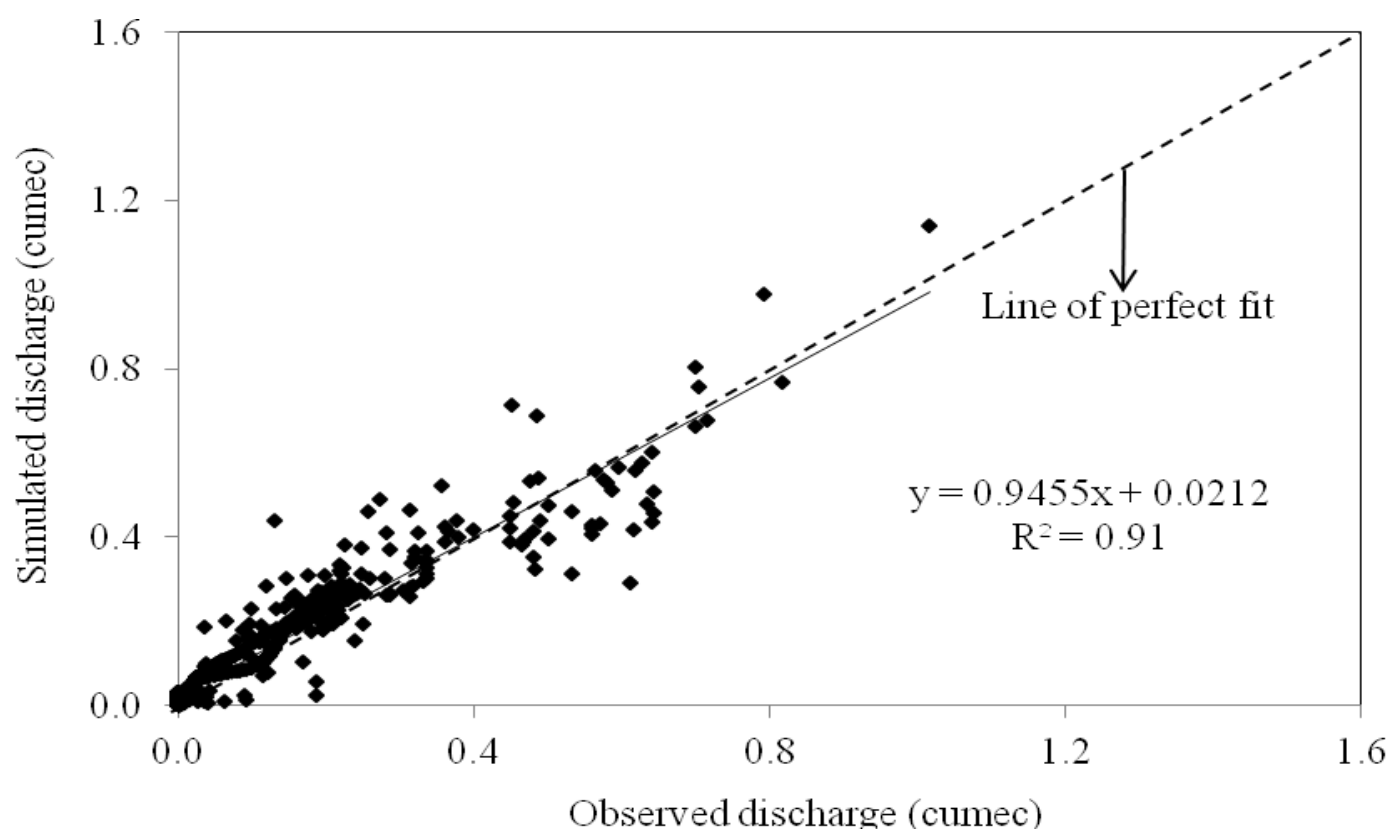

Figure 8a. Scatter plot of observed and simulated daily discharge during calibration in Bansigad watershed.

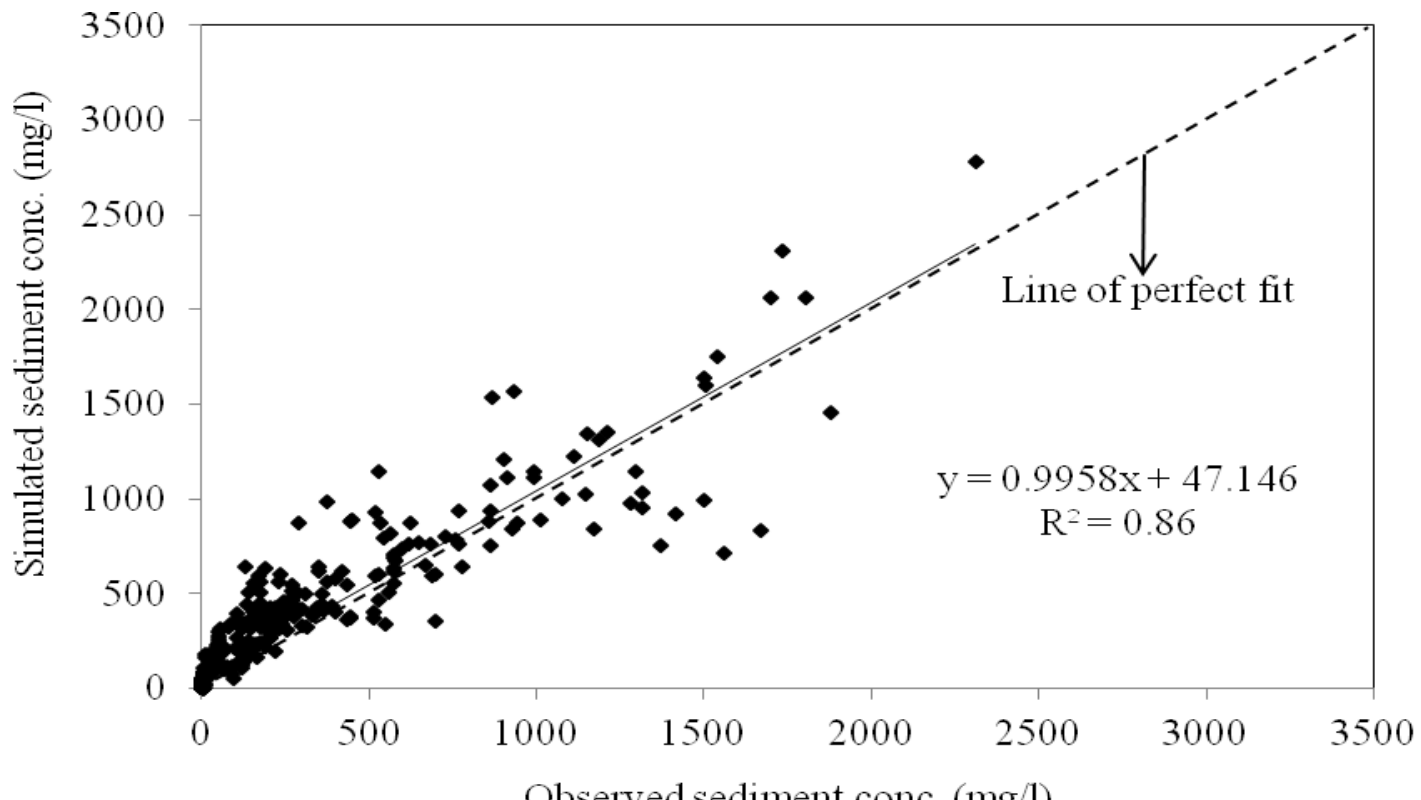

Figure 8b. Scatter plot of observed and simulated daily sediment concentration during calibration in Bansigad watershed

indicates under-prediction of the flows. Similar interpretations can also be made from the scatter plots of sediment concentration (Figures $7 \mathrm{~b}$ and $8 \mathrm{~b}$ ).

The statistical indices of model performance are presented in Tables 3 and 4 for Arnigad and Bansigad watersheds, respectively. The analysis for Arnigad watershed showed very good agreement between observed and simulated daily values, with an $\mathrm{R}^{2}$ value of 0.91 , and an $E_{N S}$ of $84.48 \%$ in discharge simulation; and an $R^{2}$ of 0.88 , and an $\mathrm{E}_{\mathrm{NS}}$ of $83.11 \%$ in sediment simulation. In Bansigad watershed too, the model exhibited a very good performance in simulating the discharge $\left(R^{2}=0.91\right.$, and $\left.\mathrm{E}_{\mathrm{NS}}=89.74 \%\right)$ and the sediment concentration $\left(\mathrm{R}^{2}=0.86\right.$ and $\left.\mathrm{E}_{\mathrm{NS}}=82.07 \%\right)$. 
Table 2. Soil properties of study watersheds.

\begin{tabular}{|c|c|c|c|c|c|c|c|c|}
\hline Depth $(\mathrm{cm})$ & $\begin{array}{l}\text { Soil organic } \\
\text { carbon (\%) }\end{array}$ & $\begin{array}{l}\text { Available water content } \\
\text { (mm water mm soil-1) }\end{array}$ & $\begin{array}{c}\text { B. D. } \\
\left(\mathrm{gm} \mathrm{cm}^{-3}\right)\end{array}$ & $\begin{array}{l}\text { Hydraulic conductivity } \\
\qquad\left(\mathrm{mm} \mathrm{h}^{-1}\right)\end{array}$ & $\begin{array}{l}\text { Sand } \\
(\%)\end{array}$ & $\begin{array}{l}\text { Silt } \\
(\%)\end{array}$ & $\begin{array}{l}\text { Clay } \\
(\%)\end{array}$ & $\begin{array}{c}\text { Soil } \\
\text { texture }\end{array}$ \\
\hline \multicolumn{9}{|c|}{ Arnigad watershed (dense oak forest) } \\
\hline $0-15$ & 3.31 & 0.142 & 1.01 & 71.42 & 67.75 & 14.00 & 18.51 & Sandy loam \\
\hline $15-30$ & 2.30 & 0.136 & 1.05 & 62.35 & 66.07 & 13.33 & 20.51 & Sandy loam \\
\hline \multicolumn{9}{|c|}{ Bansigad watershed (degraded oak forest) } \\
\hline $0-15$ & 2.37 & 0.131 & 1.06 & 65.39 & 74.27 & 11.33 & 14.40 & Sandy loam \\
\hline $15-30$ & 1.91 & 0.124 & 1.09 & 58.36 & 72.93 & 11.33 & 15.83 & Sandy loam \\
\hline
\end{tabular}

Table 3. Goodness of fit statistics for Arnigad watershed for calibration period.

\begin{tabular}{lcccccc}
\hline \multirow{2}{*}{ Description } & \multirow{2}{*}{ ENS $(\%)$} & \multirow{2}{*}{$\mathbf{R}^{2}$} & \multicolumn{3}{c}{ Mean } & \multicolumn{2}{c}{ Standard deviation } \\
\cline { 5 - 7 } & & & Observed & Simulated & Observed & Simulated \\
\hline Discharge $\left(\mathrm{m}^{3} \mathrm{~s}^{-1}\right)$ & 84.48 & 0.91 & 0.111 & 0.118 & 0.120 & 0.143 \\
Sediment concentration $\left(\mathrm{mg} \mathrm{l}^{-1}\right)$ & 83.11 & 0.89 & 82.485 & 122.820 & 172.944 & 158.658 \\
\hline
\end{tabular}

Table 4. Goodness of fit statistics for Bansigad watershed for calibration period.

\begin{tabular}{lcccccc}
\hline \multirow{2}{*}{ Description } & \multirow{2}{*}{ ENs (\%) } & \multirow{2}{*}{$\mathbf{R}^{2}$} & \multicolumn{2}{c}{ Mean } & \multicolumn{2}{c}{ Standard deviation } \\
\cline { 5 - 7 } & & & Observed & Simulated & Observed & Simulated \\
\hline Discharge $\left(\mathrm{m}^{3} \mathrm{~s}^{-1}\right)$ & 89.74 & 0.91 & 0.092 & 0.108 & 0.153 & 0.152 \\
Sediment concentration $\left(\mathrm{mg} \mathrm{l}^{-1}\right)$ & 82.07 & 0.86 & 132.128 & 178.717 & 309.983 & 332.161 \\
\hline
\end{tabular}

\section{Assessment of validation results}

For validation, the observed daily discharge and sediment concentration data of the period of June 2010 to February 2011 were utilized and compared with the model simulated values. A visual comparison of the observed and simulated daily discharge and sediment concentration is presented in Figure $9(a, b)$ for Arnigad and Figure 10( $a$ and $b$ ) for Bansigad watershed. These results show a good general agreement between observed and simulated trends of discharge and sediment concentration in both the watersheds. Further, it is observed that similar to calibration results, the peak flows are slightly overestimated in Arnigad watershed and underestimated in Bansigad watershed. The flows during non monsoon season are simulated reasonably accurate in both the watersheds. In estimating suspended sediment concentration (Figures $9 \mathrm{~b}$ and 10b), the peak values are observed to be overestimated in both the watersheds. The model also overestimated the sediment concentration during non monsoon period which is possibly due to the reason that the quantity of sediment generation also depends on the simulated discharge rate as mentioned earlier.

The scatter plots of observed and simulated daily discharge and sediment concentration are shown in Figure 11 $(a, b)$ for Arnigad and Figure 12( $a$ and $b)$ for
Bansigad watershed. Although, the data points lying above and below the line of perfect fit show some overestimation and underestimation respectively, the closeness of the data points to the line of perfect fit indicates a very good performance of the model in estimating both discharge and sediment concentration for the study watersheds. It can be seen from Tables 5 and 6 that the $R^{2}$ of 0.94 and $E_{N S}$ of $82.78 \%$ in discharge estimation, and $R^{2}$ of 0.88 and $E_{N S}$ of $83.28 \%$ in sediment estimation are computed for Arnigad watershed; and $R^{2}$ of 0.92 and $E_{\mathrm{NS}}$ of $92.5 \%$ in discharge estimation, and $R^{2}$ of 0.94 and $E_{N S}$ of $80.67 \%$ in sediment estimation are computed for Bansigad watershed. These $R^{2}$ and $E_{N S}$ values are of the same order as obtained during calibration which explain that model has performed equally well on the data set used for validation purpose. The model performance with these high values of statistical indices can be rated as more than satisfactory in simulating discharge and sediment concentration from the study watersheds. The aforementioned results can be viewed in the light of the fact that the runoff and soil erosion process in hilly and mountainous forested catchments are highly complex phenomena and affected by interaction among rainfall, runoff, soil texture and structure, land use, land slope and conservation measures. Therefore, magnitude of randomness in daily simulated values may be large in mountainous catchments 


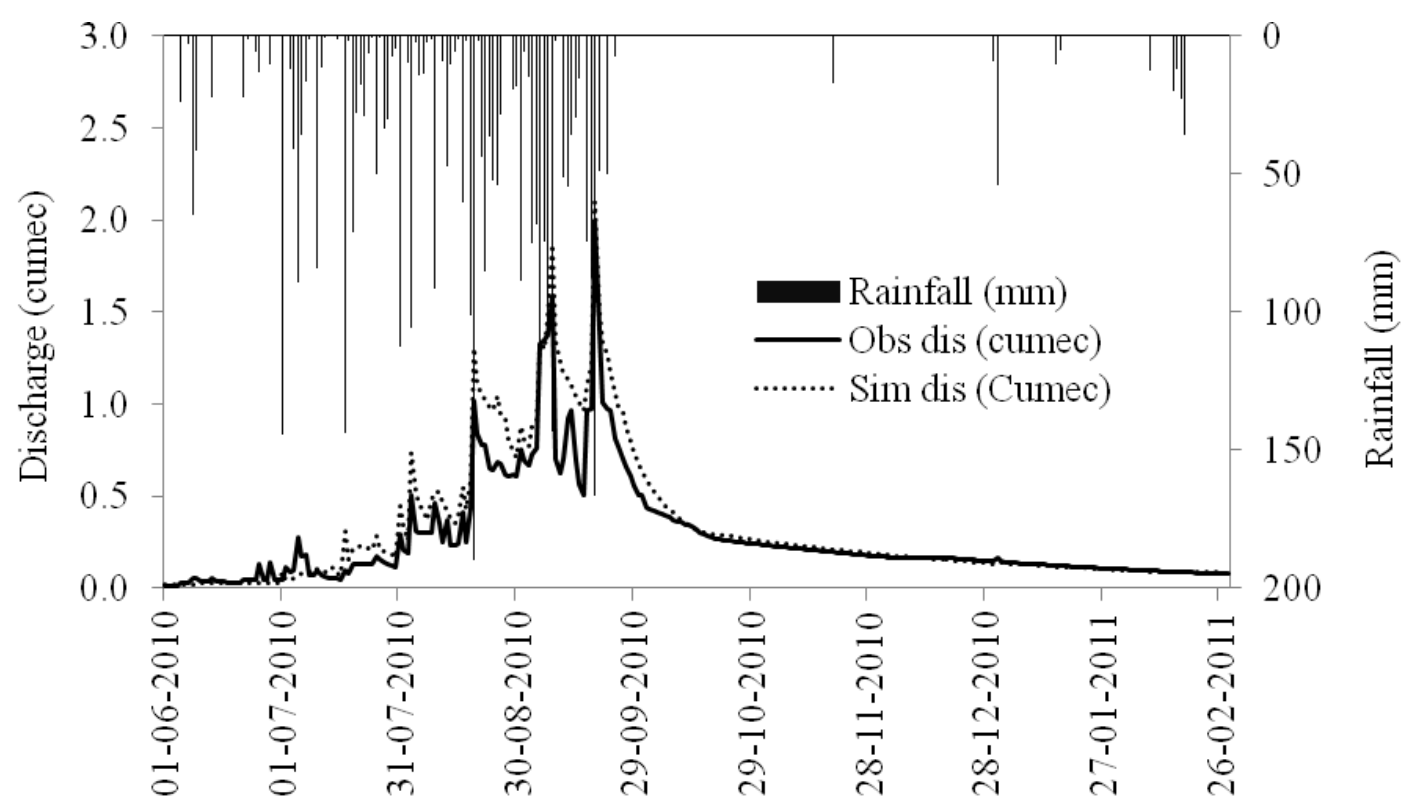

Date

Figure 9a. Observed and simulated daily discharge during validation in Arnigad watershed.

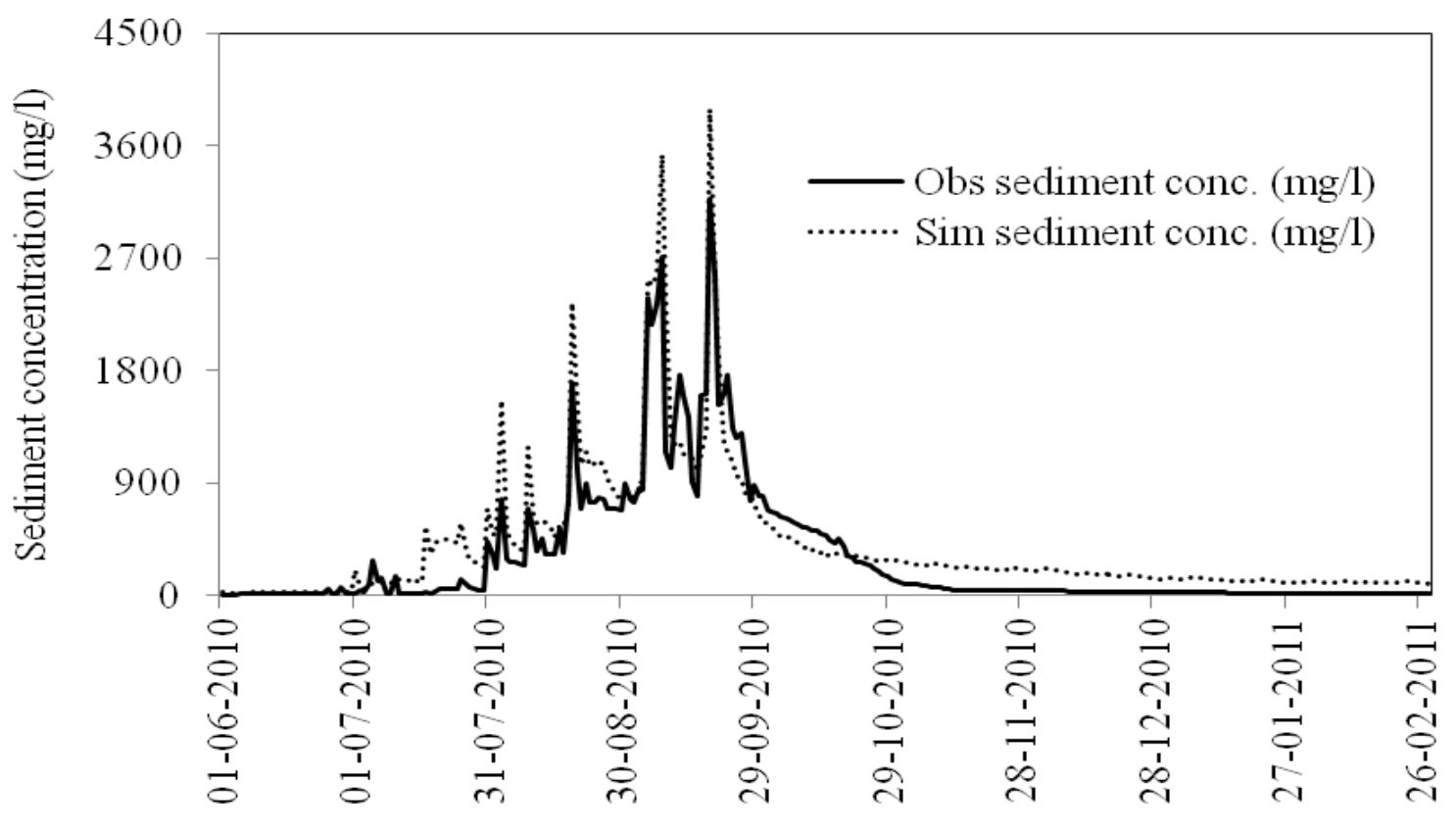

Date

Figure 9b. Observed and simulated daily sediment concentration during validation in Arnigad watershed.

(Singh et al., 2011). Generally, poor correlation among daily values in SWAT simulation has been reported in literature (Peterson and Hamlett, 1998; Varanou et al., 2002; Spruill et al., 2000).

The results of the present study, however, indicate that SWAT can be used for estimation of daily discharge and sediment from forested watersheds in lesser Himalayas.
Assessment of the impact of forest cover types on stream discharge pattern and sediment yield

The assessment of runoff and sediment yield was made based on the total simulation period of three years. The model predicted that mean annual rainfall of $2925 \mathrm{~mm}$ over Arnigad watershed was mainly partitioned among 


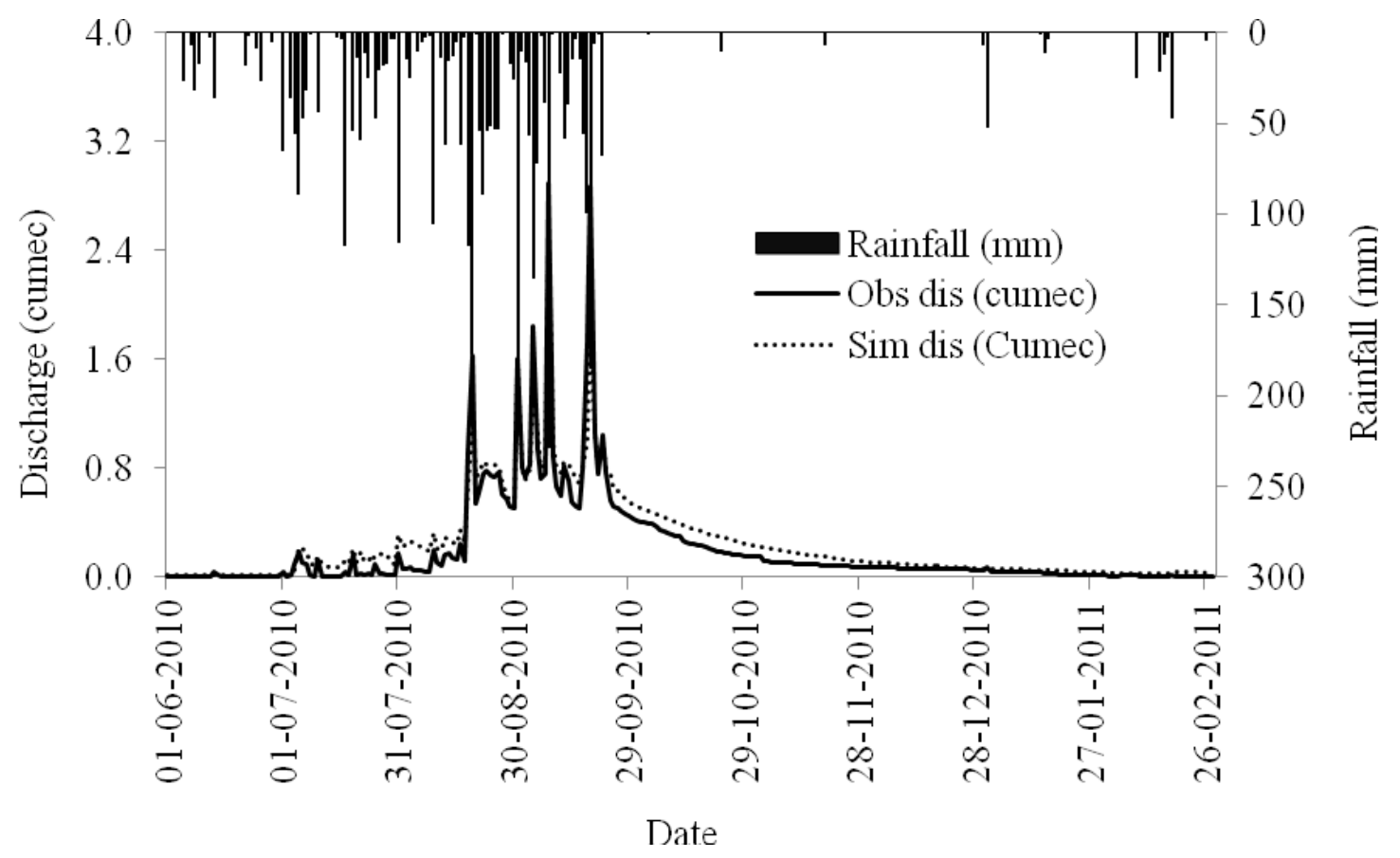

Figure 10a. Observed and simulated daily discharge during validation in Bansigad watershed.

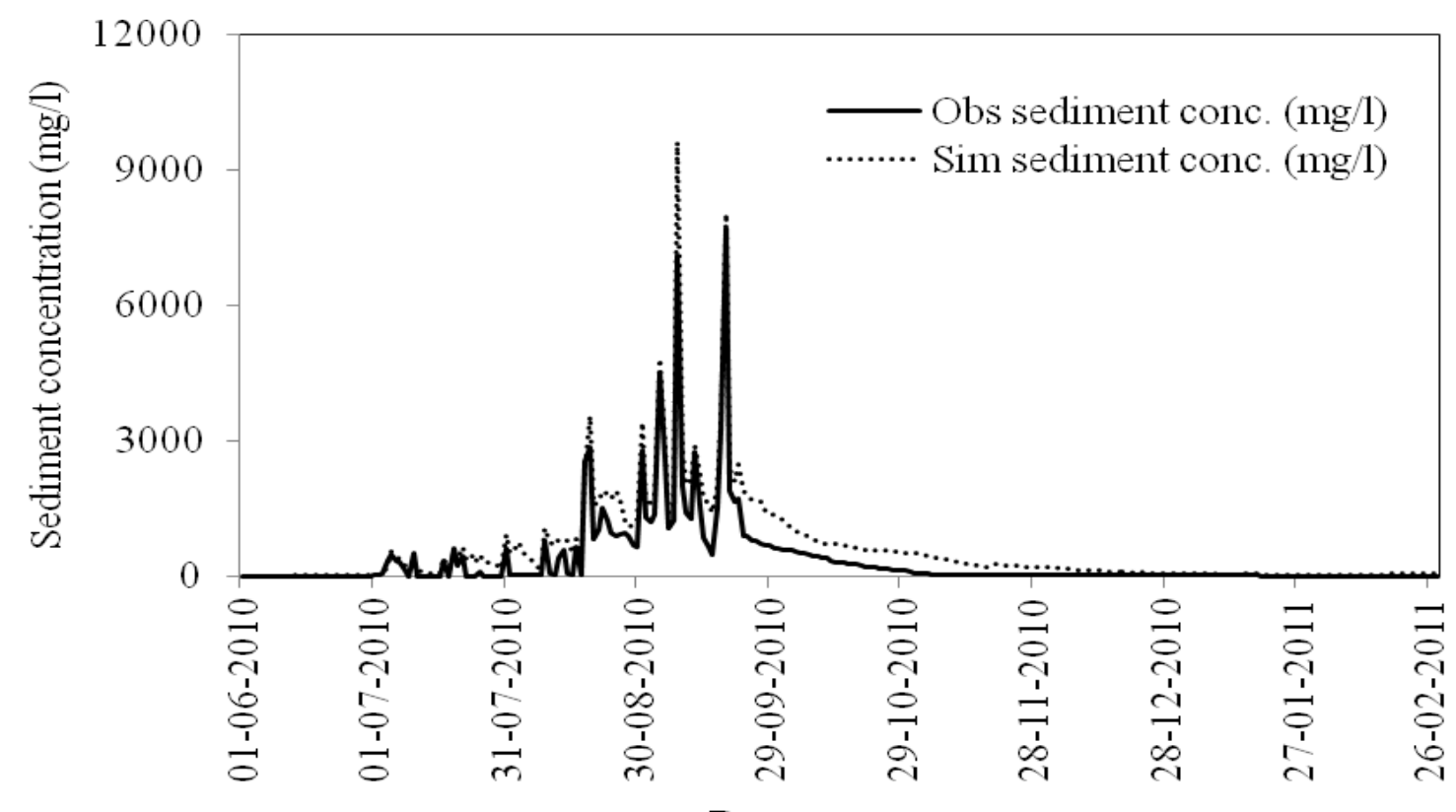

Date

Figure 10b. Observed and simulated daily sediment concentration during validation in Bansigad watershed.

evapotranspiration, ET (27.3\%), percolation/ groundwater recharge $(62.2 \%)$, transmission loss/abstraction (4.5\%) and surface runoff $(6 \%)$. The simulated mean annual water yield amounted to $1738.5 \mathrm{~mm}(59.4 \%)$ against the observed water yield of $1622.4 \mathrm{~mm}(55.5 \%)$. In Bansigad watershed, the mean annual rainfall of $2926.5 \mathrm{~mm}$ was partitioned among ET (22.1\%), percolation/groundwater recharge (65.8\%), transmission loss/abstraction (5.2\%), and surface runoff $(6.9 \%)$ and the mean annual water yield was simulated as $2030.1 \mathrm{~mm}(69.3 \%)$ against the observed value of $1863.6 \mathrm{~mm}(63.7 \%)$. These values indicate that the water balance components in both catchments are almost identical. These results can be supported by the fact that the distribution of land use and 


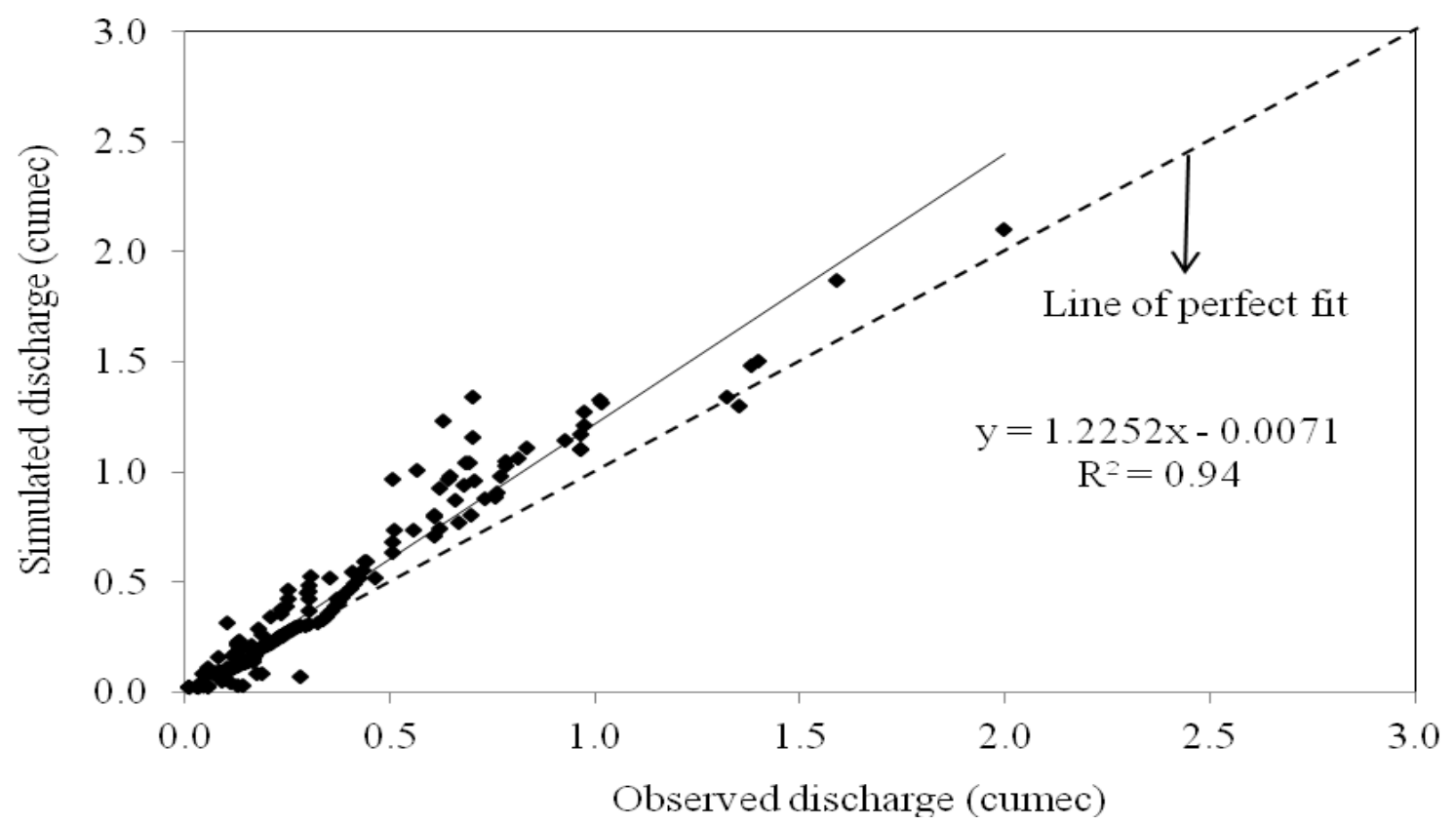

Figure 11a. Scatter plot of observed and simulated daily discharge during validation in Arnigad watershed.

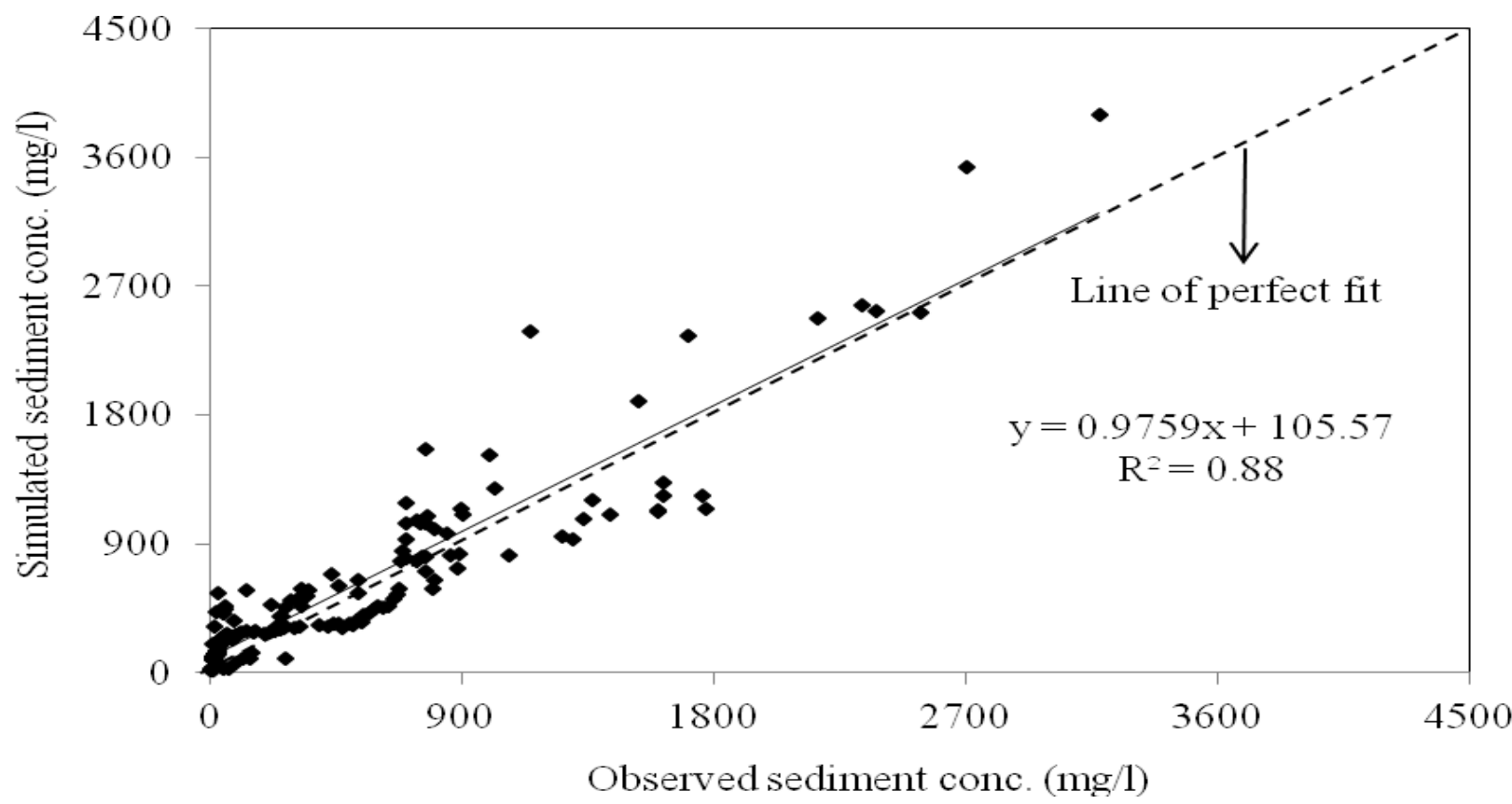

Figure 11b. Scatter plot of observed and simulated daily sediment concentration during validation in Arnigad watershed.

soil types in both the watersheds is almost similar. Higher ET and lower surface runoff in Arnigad than the Bansigad watershed is obvious due to the difference in forest cover types in Arnigad (dense Oak forest) and Bansigad watershed (degraded Oak forest). Although, higher water yield is obtained in Bansigad than the Arnigad watershed, the river flow in Bansigad ceases in the month of
February or during early March, while Arnigad sustains the river flow throughout the year. Sharda and Ojaswi (2006) reported that root system of an oak tree is very extensive and soil-root complex system of each mature oak tree has a capacity to store several hundred litres of water, which is released as base flow during the lean season. 


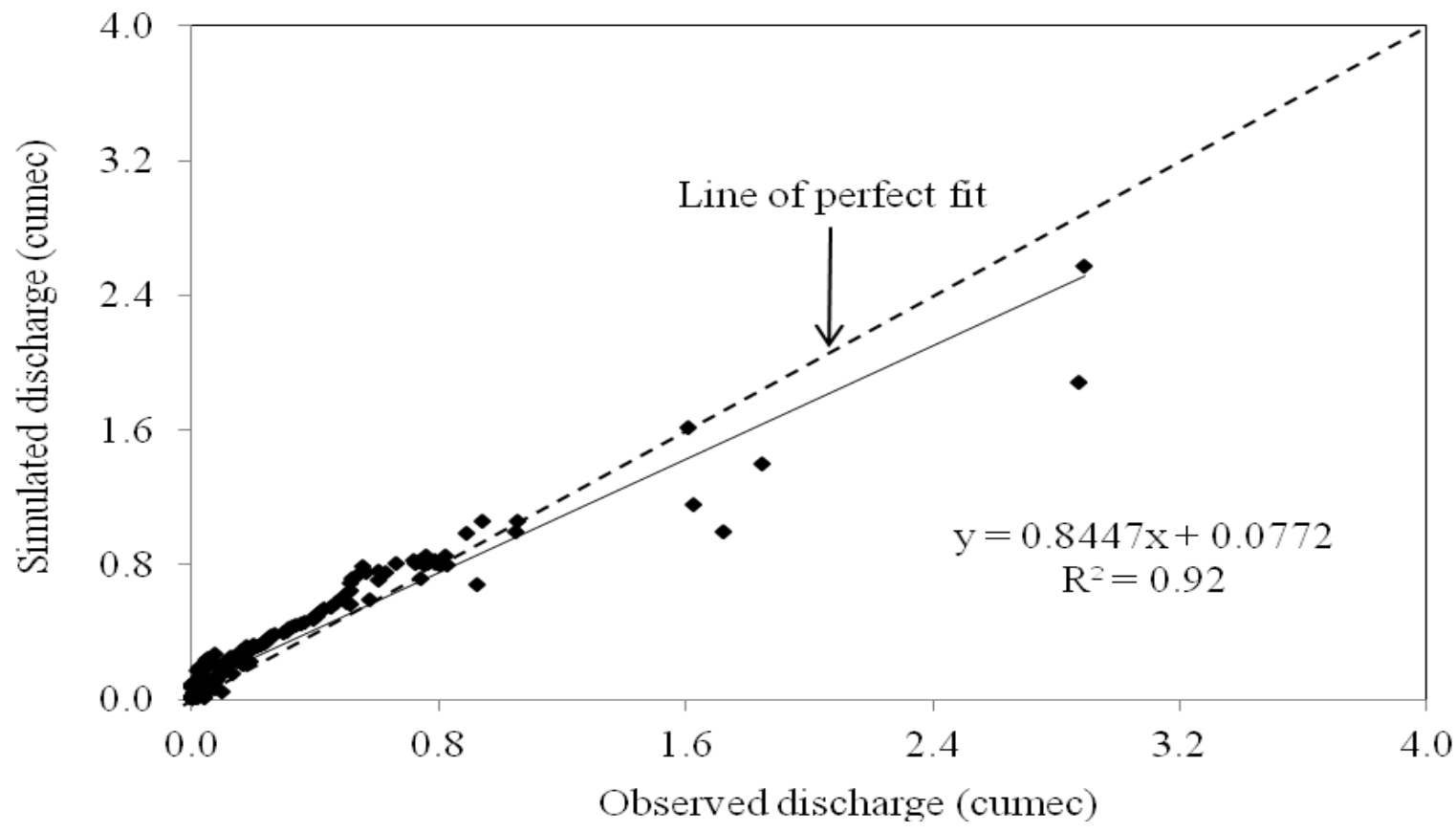

Figure 12a. Scatter plot of observed and simulated daily discharge during validation in Bansigad watershed.

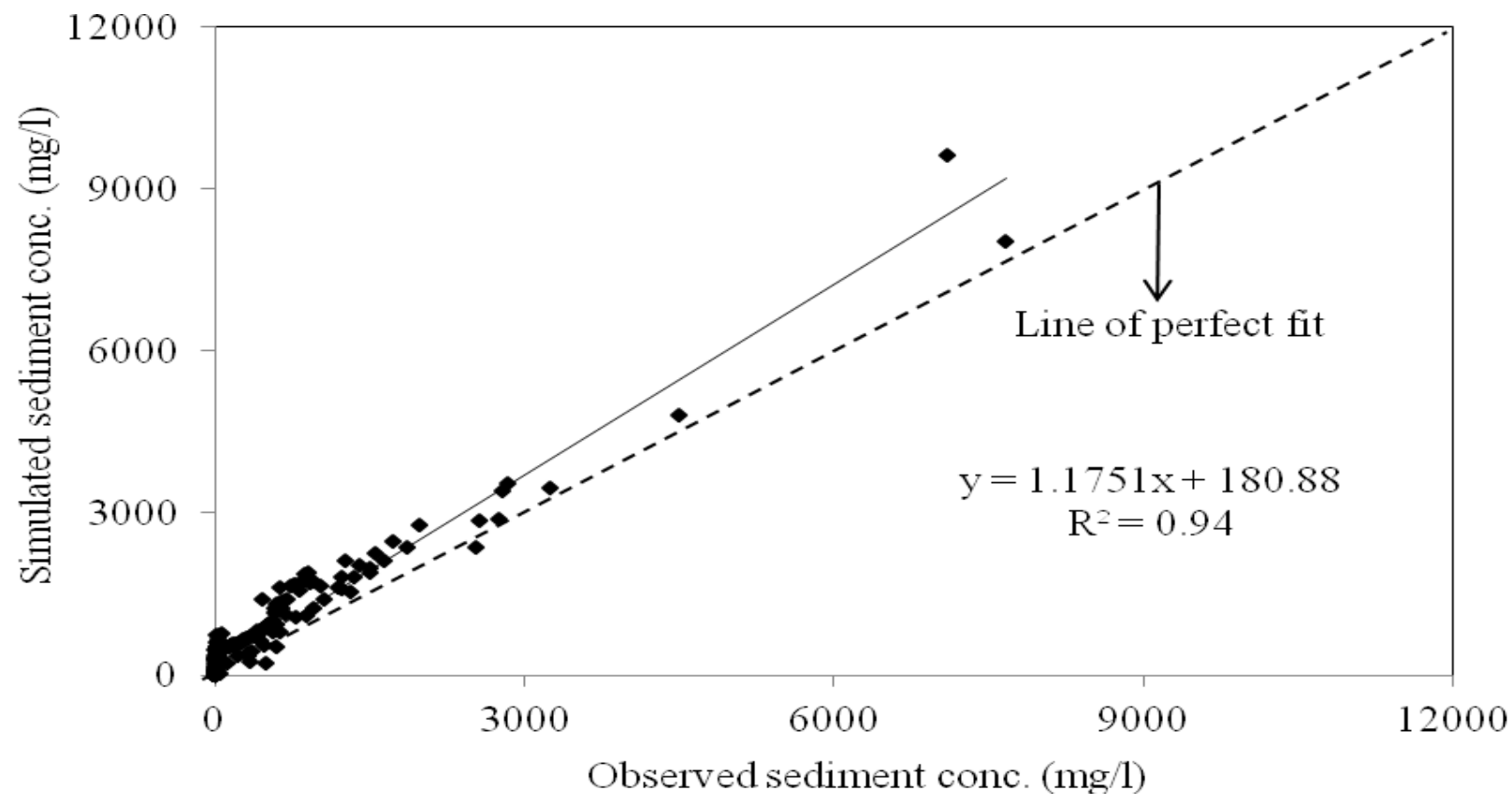

Figure 12b. Scatter plot of observed and simulated daily sediment concentration during validation in Bansigad watershed.

Table 5. Goodness of fit statistics for Arnigad watershed for validation period.

\begin{tabular}{|c|c|c|c|c|c|c|}
\hline \multirow{2}{*}{ Description } & \multirow{2}{*}{$\mathrm{E}_{\mathrm{NS}(\%)}$} & \multirow{2}{*}{$\mathbf{R}^{2}$} & \multicolumn{2}{|c|}{ Mean } & \multicolumn{2}{|c|}{ Standard deviation } \\
\hline & & & Observed & Simulated & Observed & Simulated \\
\hline Discharge $\left(\mathrm{m}^{3} \mathrm{~s}^{-1}\right)$ & 82.78 & 0.94 & 0.273 & 0.327 & 0.293 & 0.369 \\
\hline Sediment concentration ( $\mathrm{mg} \mathrm{l}^{-1}$ ) & 83.28 & 0.88 & 298.989 & 397.358 & 520.740 & 541.964 \\
\hline
\end{tabular}


Table 6. Goodness of fit statistics for Bansigad watershed for validation period.

\begin{tabular}{|c|c|c|c|c|c|c|}
\hline \multirow{2}{*}{ Description } & \multirow{2}{*}{$\mathrm{E}_{\mathrm{NS}(\%)}$} & \multirow{2}{*}{$\mathbf{R}^{2}$} & \multicolumn{2}{|c|}{ Mean } & \multicolumn{2}{|c|}{ Standard deviation } \\
\hline & & & Observed & Simulated & Observed & Simulated \\
\hline Discharge $\left(\mathrm{m}^{3} \mathrm{~s}^{-1}\right)$ & 90.50 & 0.92 & 0.205 & 0.250 & 0.378 & 0.331 \\
\hline Sediment concentration $\left(\mathrm{mg} \mathrm{l}^{-1}\right)$ & 80.67 & 0.94 & 337.922 & 577.961 & 853.365 & 1032.541 \\
\hline
\end{tabular}

The mean annual sediment loading from the Arnigad and Bansigad watershed was simulated as 8.45 and $21.97 \mathrm{t} \mathrm{ha}^{-1}$ respectively against the mean observed sediment yield of 10.70 and $24.46 \mathrm{t} \mathrm{ha}^{-1}$ in respective watersheds. The simulated sediment yield is comparable to observed values in both the watersheds. The high sediment yield in Bansigad watershed can be attributed to degraded forest cover and other anthropogenic activities in the watershed.

\section{Conclusions}

The present study was carried out to evaluate the applicability of physically based, distributed parameter SWAT model in estimating discharge and sediment yield from two forested watersheds in lower Himalaya (India) and to assess the impact of forest cover types on stream discharge and sediment yield. The following were drawn based on the results of the study:

1) The model simulated daily discharge and suspended sediment concentration followed the trend of observed values in both the watersheds.

2) $R^{2}$ values of 0.91 and above and $E_{N S}$ values of $82.8 \%$ and above both in calibration and validation exhibited high performance of SWAT in simulating the discharge from the study watersheds.

3) Similarly, the model also performed more than satisfactory on both the study watersheds in simulating the sediment concentration with $R^{2}$ values of 0.86 and above and $\mathrm{E}_{\mathrm{NS}}$ above $80 \%$.

4) The model also simulated the mean annual water yield and sediment yield close to the observed values in both the watersheds. The mean annual surface runoff and water yield over the entire study period were simulated as 6 and $59.4 \%$ respectively of the mean annual rainfall in Arnigad watershed; and 6.9 and $63.7 \%$ respectively in Bansigad watershed. The mean annual sediment yield from the respective watersheds was simulated as 8.45 and $21.97 \mathrm{t} \mathrm{ha}^{-1}$ respectively.

5) The higher ET, lower mean annual surface runoff, lower water yield and lower sediment yield from dense oak forest than that from the degraded oak forest clearly indicated the effect of forest cover types on these hydrological variables.

6) The water balance components simulated by the model provided a useful insight for examining the hydrological behaviour of study watersheds, especially the ET needs and water delivery from the watersheds which are dominated by two different forest cover types.

7) The results indicated that SWAT is capable of estimating the discharge and sediment yield from Himalayan forested watersheds, the estimates of which are often required for operation and management of irrigation and hydropower projects in the region.

\section{REFERENCES}

Arabi M, Frakenberger J, Engel BA, Arnold JG (2008). Representation of agricultural management practices with SWAT. Hydrol. Proc. 22(16):3042-3055.

Arnold JG, Srinivasan R, Muttiah RS, Williams JR (1998). Large area hydrologic modeling and assessment Part I: Model development. J. Am. Water Resour. Assoc. 34(1):73-89.

Ayana AB, Edossa DC, Kositsakulchai E (2012). Simulation of sediment yield using SWAT model in Fincha Watershed, Ethiopia. Kasetsart J. Nat. Sci. 46:283-297.

Bärlund I, Kirkkala T, Malve O, Kämäri J (2007). Assessing SWAT model performance in the evaluation of management actions for the implementation of the Water Framework Directive in a Finnish catchment. Environ. Model. Softw. 22(5):719-724.

Bartarya SK (1995). Hydrogeology and water resources of intermountain, Doon valley. Himalayan Geol. 6(2):17-28.

Beasley DB, Huggins LF, Monke EJ (1980). ANSWERS User's Manual, Purdue University, West Lafayatte.

Bhaskar NR, James WP, Devulapalli RS (1992). Hydrologic parameter estimation using geographic information system. J. Water Resour. Plan. Manage. 118(5):492-512.

Bingner RL (1996). Runoff simulated from Goodwin Creek watershed using SWAT. Trans. ASAE 39(1):85-90.

Borah DK, Bera M (2003). Watershed-scale hydrologic and nonpointsource pollution models: Review of mathematical bases. Trans. ASAE 46(6):1553-1566.

Chow VT, Maidment DR, Mays LW (Eds.) (1998). Applied Hydrology. McGraw-Hill Inc., New York.

Das S, Ruda RP, Gharabaghi B, Goel PK, Singh A, Ahmed I (2007). Comparing the performance of SWAT and AnnAGNPS model in a watershed in Ontario. ASABE publishing paper: 701P0207, ASABE, St. Joseph, MI, USA.

Hession WC, Shanholtz VO (1998). A geographic information system for targeting non-point source agricultural pollution. J. Soil Water Conserv. 43(3):264-266.

Jain SK, Kumar S, Varghese J (2004). Estimation of soil erosion for a Himalayan watershed using GIS technique. Water Res. Manage. 15(1):41-54.

Jain SK, Tyagi J, Singh V (2010). Simulation of runoff and sediment yield for a Himalayan watershed Using SWAT Model. J. Water Resour. Prot. 2:267-281.

Kannan N, White SM, Worrall F, Whelan MJ (2007). Hydrological modelling of a small catchment using SWAT 2000 - Ensuring correct flow partitioning for contaminant modelling. J. Hydrol. 334(1-2):64-72.

Kannan N, Santhi C, Arnold JG (2008). Development of an automated procedure for estimation of the spatial variation of runoff in large river basins. J. Hydrol. 359(1-2):1-15.

Knisel WG (1980). CREAMS: A Field-scale Model for chemical, runoff, and erosion from Agricultural Management Systems. USDA Conservation Research Report No. 26, Washington, D.C. 
Krause P, Boyle DP, Bäse F (2005). Comparison of different efficiency criteria for hydrological model assessment. Adv. Geosci. 5:83-87.

Leonard RA, Knisel WG, Still DA (1987). GLEAMS: Groundwater loading effects of agricultural management systems. Trans. ASAE 30(5):1403-1418.

Maidment DR (1993). GIS and hydrologic modeling. In: Environmental Modeling with GIS, eds. MF Goodchild, BO Parks, L Steyaert. New York, Oxford University Press.

Mulungu DMM, Munishi SE (2007). Simiyu River catchment parameterization using SWAT model. Phys. Chem. Earth 32:10321039.

Muttiah RS, Wurbs RA (2002). Modeling the impacts of climate change on water supply reliabilities. Water Int. Int. Water Resour. Assoc. 27(3):407-419.

Nash JE, Sutcliffe JV (1970). River flow forecasting through conceptual models: Part I. A discussion of principles. J. Hydrol. 10(3):282-290.

Neitsch SL, Arnold JG, Kiniry JR, Srinivasan R, Williams JR (2002). Soil and Water Assessment Tool (SWAT) User's Manual, Version 2000. Blackland Research Center, Grassland, Soil and Water Research Laboratory, Agricultural Research Service: Temple, TX, USA.

Neitsch SL, Arnold JG, Kiniry JR, Williams JR (2005). Soil and Water Assessment Tool: Theoretical Documentation. Blackland Research Center, Grassland, Soil and Water Research Laboratory, Agricultural Research Service: Temple, TX, USA.

Oeurng C, Sauvage S, Sánchez-Pérez JM (2011). Assessment of hydrology, sediment and particulate organic carbon yield in a large agricultural catchment using the SWAT model. J. Hydrol. 401:145153.

Pandey VK, Panda SN, Sudhakar S (2005). Modelling of an agricultural watershed using remote sensing and a geographic information system. Biosyst. Eng. 90(3):331-347.

Pandey VK, Panda SN, Pandey A, Sudhakar S (2009). Evaluation of effective management plan for an agricultural watershed using AVSWAT model. Rem. Sens. GIS. Environ. Geol. 56:993-1008.

Parajuli PB, Mankin KR, Barnes PL (2007). New Methods in Modeling Source Specific Bacteria Scale using SWAT. ASABE publication No. 701P0207. ASABE: St. Joseph, MI, USA.

Peterson JR, Hamlett JM (1998). Hydrologic calibration of the SWAT model in a watershed containing fragipan soils. J. Am. Water Res. Assoc. 34(3):531-544.

Rautela P, Joshi GC, Bhaisora B (2010). Seismic vulnerability and risk in the Himalayan township of Mussoorie, Uttarakhand, India. Curr. Sci. 99(4):521-526.

Rosenthal WD, Srinivasan R, Arnold JG (1995). Alternative river management using a linked GIS-hydrology model. Trans. ASAE 38(3):783-790.

Sharda VN, Ojaswi PR (2006). Hydrological evaluation of forest tree covers in different agro-ecological regions of India. Paper presented in Int. Workshop on Impacts of Reforestation of Degraded Lands on Landscape hydrology in the Asian region, 6 -10 March 2006, Roorkee, India.

Singh RK, Panda RK, Satapathy KK, Ngachan SV (2011). Simulation of runoff and sediment yield from a hilly watershed in the eastern Himalaya, India using the WEPP model. J. Hydrol. 405(3-4):261-276.

Smith R (1992). OPUS, An integrated simulation model for transport of nonpoint sources pollutants at the field scale, Volume I: Documentation. ARS-95. Washington, D.C.: USDA Agricultural Research Service.

Spruill CA, Workman SR, Taraba JL (2000). Simulation of daily and monthly stream discharge from small watersheds using the SWAT model. Trans. ASAE 43(6):1431-1439.

Srinivasan R, Engel BA (1991). A Knowledge Based Approach to Extract Input Data From GIS. ASAE Paper No. 91-7045.

Srinivasan R, Ramanarayanan TS, Jayakrishnan R,Wang H (1997). Hydrologic modeling of Rio Grande/Rio Bravo basin. ASAE Paper No. 97-2236. St. Joseph, Mich.: ASAE.

Srinivasan M S, Gerald-Marchant P, Veith TL, Gburek WJ, Steenhuis TS (2005). Watershed-scale modeling of critical source areas of runoff generation and phosphorus transport. J. Am. Water Resour. Assoc. 41(2):361-375.
Thakur VC, Pandey AK (2004). Late Quaternary tectonic evolution of Dun in fault bend/ propagated fold system, Garhwal Sub-Himalaya. Curr. Sci. 87(11):1567-1576.

Tolson BA, Shoemaker CA (2007). Cannonsville reservoir watershed SWAT2000 model development, calibration, and validation. J. Hydrol. 337(1-2):68-86.

Tripathi MP, Panda RK, Raghuwanshi NS (1999). Runoff estimation from a small watershed using SWAT model. Proceeding of International Conference on Water, Environment, Ecology, SocioEconomics and Health Engineering Seoul, Korea 143-152.

Tripathi MP, Panda RK, Raghuwanshi NS (2003). Identification and prioritisation of critical sub-watersheds for soil conservation management using the SWAT model. Biosyst. Eng. 85(3):365-379.

USDA Soil Conservation Service (1972). National Engineering Handbook. Hydrology Section 4 (Chapters 4-10).

Varanou E, Gkouvatsou E, Baltas E, Mimikou M (2002). Quantity and quality integrated catchment modeling under climate change with use of soil and water assessment tool model. J. Hydrol. Eng. 7(3):228244.

Wang S, Kang S, Zhang L, Li F (2008). Modeling hydrological response to different land use and climate change scenarios in the Zamu River basin of northwest China. Hydrol. Proc. 22:2502-2510.

Williams JR (1975). Sediment yield prediction with universal equation using runoff energy factor. In: Present and Prospective Technology for Predicting Sediment Yield and Sources, Proceeding of the Sediment Yield Workshop. USDA Sedimentation Lab., Oxford, MS, USA. 28-30 November, 1972, p. 244-252.

Williams JR, Renard KG, Dyke PT (1983). EPIC: A new method for assessing erosion's effect on soil productivity. J. Soil Water Conserv. 38(5):381-383.

Williams JR, Nicks AD, Arnold JG (1985). SWRRB, a simulator for water resources in rural basins. ASCE Hydrol. J. 111(6):970-986.

Xu ZX, Pang JP, Liu CM, Li JY (2009). Assessment of runoff and sediment yield in the Miyun Reservoir catchment by using SWAT model. Hydrol. Proc. 23: 3619-3630.

Young RA, Onstad DD, Anderson WP (1989). AGNPS: A nonpoint source pollution model for evaluating agricultural watersheds. Soil and Water Cons. 44(2): 168-173. 